\title{
NILAI-NILAI TARBIYAH IBADAH KURBAN DAN RELEVANSINYA DENGAN PEMBELAJARAN PENDIDIKAN FORMAL
}

\author{
Muhammad Alqadri Burga*, Andi Marjuni** \& Rosdiana*** \\ Universitas Islam Negeri Alauddin Makassar \\ *qadriburga@gmail.com \\ **h.marjunij@yahoo.com
}

\begin{abstract}
This research analyzes the value of Islamic education in the history of kurban worship according to QS al-Saffat/37: 100-108 and its relevance to instruction in formal education. The type of research used is qualitative with the text study method. In addition to that, it views the issue through normative theological, interpretical, philosophical, and pedagogical approaches. Data are collected through documentation and then analyzed using the content analysis method. The results of the research show that the history of kurban worship according to QS al-Saffat/37: 100-108 is divided into four episodes: (1) expectations, (2) test, (3) pass the test, and (4) rewards. There are eight values of Islamic education found in kurban worship, namely: (1) faith, (2) morals, (3) patience, (4) resignation, (5) sincerity, (6) democratic, (7) dialogue, and (8) social. The value of Islamic education in the history of kurban worship has relevance to the main characteristics of learning design and the learning process which consists of planning, implementation, evaluation, and follow-up. In addition, it accommodates all values that will be developed in character education.
\end{abstract}

Keywords: Formal Education, Instruction, Islamic Education Values, Kurban Worship

\begin{abstract}
Abstrak: Tujuan penelitian ini adalah untuk menganalisis nilai-nilai tarbiyah dalam sejarah ibadah kurban menurut QS al-Șaffāt/37: 100-108 dan relevansinya dengan pembelajaran pendidikan formal. Jenis penelitian yang digunakan adalah kualitatif dengan metode studi teks/pustaka. Pendekatan yang digunakan adalah normatif teologis, tafsir, historis, filosofis, dan pedagogis. Data dikumpulkan melalui dokumentasi kemudian dianalisis menggunakan metode content analysis (analisis isi). Hasil penelitian menunjukkan bahwa sejarah ibadah kurban menurut QS alȘaffāt/37: 100-108 dibagi ke dalam empat episode, yaitu; (1) harapan, (2) ujian, (3) lulus ujian, dan (4) penghargaan. Nilai-nilai tarbiyah yang ditemukan dalam ibadah kurban ada delapan, yaitu; (1) keimanan, (2) akhlak, (3) kesabaran, (4) tawakkal, (5) keikhlasan, (6) demokratis, (7) dialogis, dan (8) sosial. Nilai-nilai tarbiyah dalam sejarah ibadah kurban memiliki relevansi dengan karakteristik utama desain pembelajaran dan proses pembelajaran yang terdiri dari perencanaan, pelaksanaan, evaluasi, dan tindak lanjut. Selain itu, mengakomodasi seluruh nilai yang hendak dikembangkan dalam pendidikan karakter.
\end{abstract}

Kata Kunci: Nilai Tarbiyah, Ibadah Kurban, Pembelajaran, Pendidikan Formal 


\section{PENDAHULUAN}

Ibadah kurban menurut QS al-Ṣaffāt/37: 100-108 merupakan salah satu sejarah dalam al-Qur'an yang menarik untuk dikaji. Di samping sebagai latar belakang hari raya Islam (Idul Adha), juga menggambarkan kesuksesan Nabi Ibrahim sebagai seorang kepala rumah tangga, orang tua, dan pendidik dalam mengembangkan potensi intelektual, emosional, dan spiritual keluarganya. ${ }^{1}$ Sejarah tersebut merupakan dokumentasi yang tetap aktual dan selalu menarik untuk dikaji. Ia juga menyediakan samudera hikmah yang tidak habis diselami. Suatu episode memikat dari sejarah besar itu adalah percakapan ayah-anak antara Ibrahim dan Ismail yang mengawali kisah penyembelihan masyhur dari generasi ke generasi. Terdapat nilai-nilai tarbiyah di balik sejarah besar tersebut yang dapat diambil sebagai konsep untuk diaplikasikan dalam kehidupan khususnya dalam dunia pendidikan.

Kajian ibadah kurban dalam perspektif pendidikan baru menyentuh ranah nonformal. ${ }^{2}$ Bahkan, secara umum pembahasannya hanya berkutat pada kajian ibadah sebagai sarana mendekatkan diri kepada Allah SWT dan kajian nilai sosial kemasyarakatan. ${ }^{3}$ Tuntutan kesempurnaan ilmu pengetahuan mengenai konsep pendidikan Islam dalam nilainilai tarbiyah (pendidikan Islam) ibadah kurban dan relevansinya dengan pembelajaran pendidikan formal belum dikaji sebagaimana keinginan penulis. Kajian ini menjadi penting karena merupakan kontekstualisasi dimensi tarbawi ibadah kurban dalam pembelajaran pendidikan formal sebagai respons terhadap globalisasi.

Tidak dapat dipungkiri, dunia pembelajaran pendidikan formal dewasa ini didominasi oleh konsep pendidikan Barat yang lebih mengutamakan kognisi ketimbang afeksi dan kering akan nilai spiritual. ${ }^{4}$ Hadirnya berbagai kecenderungan di era globalisasi merupakan tantangan bagi pendidikan Islam dan sekaligus menjadi peluang jika mampu

${ }^{1}$ H. M. Amir, Kisab Nabi Ibrahim dalam Al-Qur'an dan Relevansinya dengan Pendidikan Islam. Ekspose, Vol. 23, No. 1 (2014): 1-22.

2Zainol Hasan, Nilai-nilai tarbiyah pada Kisah Nabi Ibrabim. Nuansa: Jurnal Penelitian Ilmu Sosial dan Keagamaan Islam, Vol. 14, No. 2 (2018): 423-450. Lihat juga Achmad Widadi, Nilai Pendidikan pada Syariat Kurban: Kajian Tafsir Surat Al-Haij Ayat 34 dan Surat Al-Kautsar Ayat 1-3. Jakarta: FITK UIN Syarif Hidayatullah, 2016.

${ }^{3}$ Reni Noviati, Praktik Kurban Online dalam Perspektif Islam Tebar Hewan Kurban (THK) di Dompet Dhuafa. Syarikah: Jurnal Ekonomi Islam, Vol. 3, No. 1 (2017): 343-357. Choirul Mahfud, Tafsir Sosial Kontekstual Ibadah Kurban dalam Islam. Humanika, Vol. 14, No. 1 (2014): 1-16. Assyari Abdullah, "Komunikasi Simbolik Ibadah Kurban", RiauPos.co, 25 September 2015, http://www.riaupos.co/4085-opini-komunikasi-simbolik-ibadah-kurban.html (Diakses 13 Januari 2018).

${ }^{4}$ Muhammad Alqadri Burga, Hakikat Manusia sebagai Makbluk Pedagogik. Al-Musannif, Vol. 1, No. 1 (2019): 19-31. 
dihadapi secara bijaksana, ${ }^{5}$ dengan kembali merumuskan desain pendidikan berdasarkan komponen pendidikan: visi, misi, tujuan, kurikulum, proses pembelajaran berdasarkan alQur'an dan hadis. 6 Menghadapi keadaan tersebut, pendidikan Islam mesti melakukan pengembangan tanpa melupakan visi utamanya, yaitu membentuk manusia seutuhnya yang terbina seluruh potensinya secara seimbang berdasarkan al-Qur'an dan hadis.

Berdasarkan diskursus tersebut, penelitian ini akan mengkaji nilai tarbiyah dalam sejarah ibadah kurban menurut QS al-Șaffāt/37: 100-108 dengan memfokuskan pada tiga pokok masalah, yaitu: 1) sejarah ibadah kurban menurut Q.S. al-Ṣaffāt/37: 100-108, 2) nilainilai tarbiyah dalam sejarah ibadah kurban, dan 3) relevansi nilai tarbiyah dalam sejarah ibadah kurban dengan pembelajaran pendidikan formal. Kajian ini penting untuk dilakukan sebagai gambaran eksistensi pendidikan Islam yang berorientasi nilai di tengah tuntutan pendidikan modern yang sifatnya administratif dengan capaian formalistik. ${ }^{7}$

\section{METODE DAN PENDEKATAN PENELITIAN}

Jenis penelitian ini adalah kualitatif dengan metode studi teks/pustaka, yaitu mengadakan pengkajian berdasarkan analisis dokumen. Penelitian ini tidak menghimpun data secara interaktif melalui interaksi dengan sumber data manusia, tetapi peneliti menghimpun, mengidentifikasi, menganalisis, dan mengadakan sintesis data untuk kemudian memberikan interpretasi terhadap QS. al-Ṣaffāt/37: 100-108 mengenai konsep nilai-nilai tarbiyah dalam ibadah kurban dan relevansinya dengan pembelajaran pendidikan formal. ${ }^{8}$ Pendekatan penelitian yang digunakan adalah: 1) Pendekatan teologis normatif untuk melihat sejarah ibadah kurban menurut QS. al-Ṣaffāt/37: 100-108; 2) pendekatan tafsir untuk menganalisis makna tersirat dalam QS. al-Ṣaffāt/37: 100-108 kaitannya dengan ibadah kurban; 3) pendekatan historis untuk melihat sejarah ibadah kurban; 4) pendekatan filosofis untuk menganalisis nilai-nilai tarbiyah dalam ibadah kurban; dan 5) pendekatan pedagogis untuk menganalisis relevansi nilai-nilai tarbiyah ibadah kurban dengan pembelajaran pendidikan formal.

${ }^{5}$ Nur Latifah, Pendidikan Islam di Era Globalisasi. PALAPA: Jurnal Studi Keislaman dan Ilmu Pendidikan, Vol. 5, No. 1 (2017): 196-208.

${ }^{6}$ Abuddin Nata, Kapita Selekta Pendidikan Islam (Jakarta: PT. Raja Grafindo Persada, 2012), 2.

${ }^{7}$ Muhammad Alqadri Burga, dkk., Accommodating the National Education Policy in Pondok Pesantren DDI Mangkoso: Study Period of 1989-2018. Islam Realitas: Journal of Islamic \& Social Studies, Vol. 5, No. 1 (2019): 78-95.

${ }^{8}$ Asep Saepul Hamdi dan E. Baharuddin, Metodologi Penelitian Kuantitatif: Aplikasi dalam Pendidikan (Yogyakarta: Deepublish, 2015), 12. 
Sumber data penelitian ini adalah al-Qur'an dan berbagai dokumen dalam bentuk buku, jurnal, serta karya ilmiah lainnya yang berkaitan dengan nilai tarbiyah dalam Ibadah kurban menurut QS. al-Șaffāt/37: 100-108 dan relevansinya dengan pembelajaran pendidikan formal. Data yang telah didokumentasikan dianalisis menggunakan metode content analysis (analisis isi) ${ }^{9}$ melalui tahap: reduksi data, penyajian data, dan penarikan kesimpulan. ${ }^{10}$ Reduksi data merupakan proses pemilihan data yang memiliki relevansi dengan pokok masalah sehingga memiliki nilai temuan dan pengembangan teori yang signifikan. Setelah data direduksi, langkah selanjutnya adalah menyajikan data dalam bentuk uraian deskriptif yang bersifat naratif sehingga menghasilkan informasi yang dapat dipahami. ${ }^{11}$ Informasi tersebut disusun berdasarkan pola tertentu sehingga memungkinkan adanya penarikan kesimpulan, yaitu upaya untuk mengartikan data yang ditampilkan dengan melibatkan pemahaman peneliti dalam konteks kerangka teori. ${ }^{12}$ Kesimpulan dalam penelitian ini merupakan jawaban permasalahan yang dirumuskan sejak awal sebagai pokok masalah.

\section{IBADAH KURBAN MENURUT QS AL-ȘAFFĀT/37: 100-108}

QS al-Ṣaffāt/37: 100-108 menjelaskan sejarah ibadah kurban yang dibagi ke dalam empat episode, yaitu: harapan, ujian, lulus ujian, dan penghargaan. Pembagian episode ini menjadi tema keadaan Ibrahim dalam sejarah ibadah kurban dan memperjelas esensi dari keadaan tersebut.

\section{Episode I (Harapan)}

Ibrahim diselamatkan oleh Allah SWT. dari tipu daya ${ }^{13}$ kaumnya yang enggan meninggalkan persembahan pada berhala-berhala dan tetap menolak serta mengingkari kenabian Ibrahim meskipun telah melihat dengan mata kepala mukjizatnya. Ia pun meninggalkan kaum dan keluarganya seraya berdoa kepada Allah SWT mengharapkan hidayah dan pengganti dari keluarga yang ia tinggalkan, ${ }^{14}$ sebagaimana disebutkan dalam QS al-Ṣaffāt/37: 100-101.

\footnotetext{
${ }^{9}$ Metode analisis tentang isi pesan suatu komunikasi. Maksud dari isi pesan suatu komunikasi di sini adalah isi atau pesan dari sumber-sumber data yang telah diperoleh oleh peneliti. Lihat Noeng Muhadjir, Metode Penelitian Kualitatif (Yogyakarta: Rake Sarasih, 2002), 49.

${ }^{10}$ Sugiyono, Memahami Penelitian Kualitatif (Bandung: Alfabeta, 2009), 92.

${ }^{11}$ Imam Suprayogo dan Tabroni, Metode Penelitian Sosial-Agama (Bandung: Remaja Rosda-karya, 2001), 194.

${ }^{12}$ Bagong Suyanto et. al., Metode Penelitian Sosial: Berbagai Alternatif Pendekatan (Jakarta: Kencana, 2007), 246.

${ }^{13}$ Kobaran api yang disiapkan untuk membakar Ibrahim. Lihat QS al-Ṣaffāt/37: 97-99.

${ }^{14} \mathrm{Ibnu}$ Kașìr, Tafsì al-Qur'ān al-'Ażim, Jilid VII (Kuala Lumpur Victory Agencie, 2006), 23.
} 


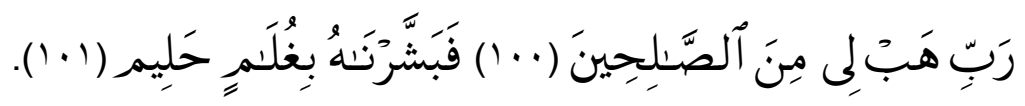

Terjemahnya:

100. Wahai Tuhanku, anugrahkanlah kepadaku (seorang anak) yang termasuk orang-orang yang saleh.

101. Maka kami beri kabar gembira kepadanya dengan (kelahiran) seorang anak yang sangat sabar (Ismail). ${ }^{15}$

Ayat tersebut menjelaskan harapan Ibrahim yang sudah memasuki usia lanjut, yaitu 86 tahun untuk memiliki anak saleh yang dapat meneruskan perjuangannya dalam menyebarkan ajaran tauhid. ${ }^{16}$ Harapan tersebut diungkapkannya melalui doa "Rabbi babli min al-sḥälibìn”. Doa tersebut diperjelas oleh al-Marāgī:

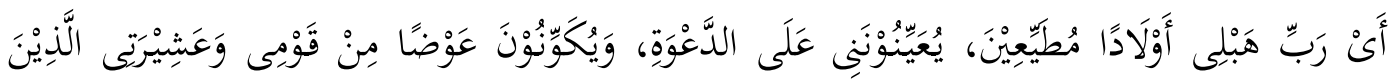

Artinya:

Yaitu wahai Tuhanku, anugerahkanlah kepadaku anak yang taat, yang menemaniku berdakwah, dan sebagai pengganti kaum dan keluargaku yang aku tinggalkan (jauh dariku).

Penjelasan mengenai doa tersebut menunjukkan rasa kesepian dan kegelisahan Ibrahim dalam keterasingannya jauh dari kaum dan keluarganya. ${ }^{18}$ Allah mengabulkan doa Ibrahim dalam firmannya "fabasysyarnāhu bi guläm halìm" (maka kami beri dia kabar gembira dengan seorang anak yang amat sabar), maksudnya ketika menjadi dewasa, anak itu memiliki sifat sabar. ${ }^{19}$

Menurut Ibnu Kasīir, guläm halim yang dimaksud Allah SWT. dalam ayat tersebut adalah Ismail. Dia mengedepankan beberapa argumentasi, yaitu: Pertama, Ismail adalah anak pertama yang dilahirkan dan menjadi kabar gembira bagi Ibrahim. Kedua, Ismail juga lebih tua dari Ishak. Ismail lahir ketika Ibrahim berusia delapan puluh enam tahun, sedangkan Ishak

\footnotetext{
${ }^{15}$ Departemen Agama RI, Al-Qur'an dan Terjemahnya (Surabaya: Pustaka Assalam, 2010), 641.

${ }^{16}$ Abdul Malik Karim Amrullah, Tafsir al-Az̧har, Juzz XXIII (Jakarta: Pustaka Panjimas, 2008), 144.

${ }^{17}$ Aḥmad Musțāfa al-Marāgī, Tafür al-Marāgì, Juzz XXIII. (Semarang: Toha Putra, 1993), 72.

${ }^{18}$ Ibrahim berada di Negeri Syam. Lihat Muḥammad 'Alī al-Șābūnī, Shafwah al-Tafasir: Tafsìr li al-Qur'àn al-Karim, Jilid III (Jakarta Indonesia: Dar al-Kutub al-Islamiyyah: 1999), 39.

${ }^{19}$ Al-Qurțubī, Tafsì al-Qurtubì, Jilid XV (Jakarta: Pustaka Azzam, 2009), 232.
} 
lahir saat Nabi Ibrahim berusia sembilan puluh sembilan tahun. ${ }^{20}$ Jumhur ulama mengemukakan hal serupa, bahwa anak yang menjadi kabar gembira tersebut adalah Ismail dengan argumentasi, sesudah sempurna kisah penyembelihan barulah Allah SW'T memberi kabar gembira kedua kepada Ibrahim dengan seorang anak bernama Ishak yang akan menjadi nabi dari orang-orang yang saleh. ${ }^{21}$ Sehingga, Ibrahim diberi gelar gulam halim, yaitu remaja cerdas yang mengutamakan hati ketimbang nalarnya dalam merespons perintah Allah. Sementara Ishak diberi gelar guläm 'alìm, yaitu remaja yang memiliki kecerdasan intelektual yang luar biasa.

\section{Episode II (Ujian)}

Ibrahim diuji oleh Allah dengan ujian yang berat. Allah memerintahkan kepada Ibrahim untuk menyembelih Ismail sebagai kurban di sisi Allah. Sebagaimana dijelaskan QS al-Ṣaffāt/37: 102.

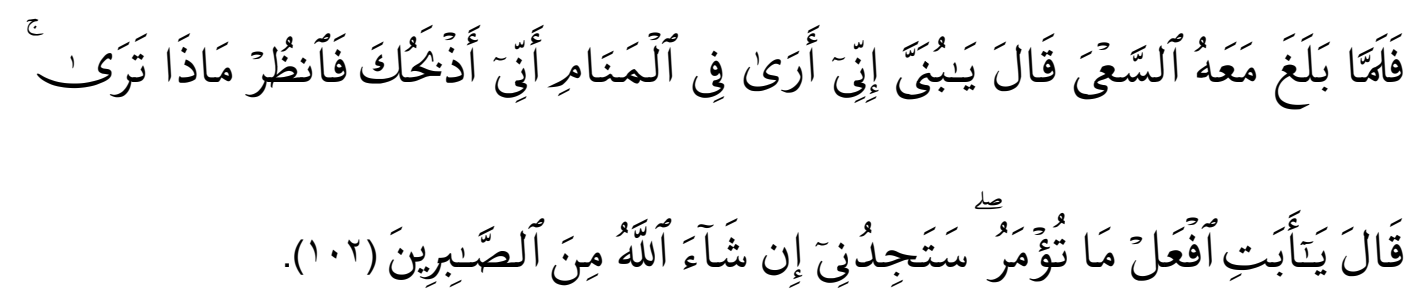

Terjemahnya:

Maka tatkala anak itu sampai (pada umur sanggup) berusaha bersama-sama Ibrahim, Ibrahim berkata: "Hai anakku sesungguhnya Aku melihat dalam mimpi bahwa aku menyembelihmu. Maka pikirkanlah apa pendapatmu" ia menjawab: "Hai bapakku, kerjakanlah apa yang diperintahkan kepadamu; insya Allah kamu akan mendapatiku termasuk orang-orang yang sabar". ${ }^{22}$

Kata al-sa'ya menunjukkan bahwa saat itu Ismail memasuki masa balig atau remaja, suatu tingkatan umur dimana anak dapat membantu pekerjaan orang tuanya. Menurut alFarra', usia Ismail saat itu 13 tahun ${ }^{23}$ dan suatu pendapat 17 tahun. ${ }^{24}$ Ketika itu, Ibrahim dengan

\footnotetext{
${ }^{20} \mathrm{Ibnu}$ Kașīr, Tafsìr al-Qur'ān al-'Aż̀m, 23.

${ }^{21}$ Muḥammad 'Alī al-Ṣabūnī, Shafivah al-Tafasìr, 39.

22Departemen Agama RI, Al-Qur'an dan Terjemahnya, 641.

23Departemen Agama RI, Al-Qur'an dan Tafsirnya: Edisi yang Disempurnakan, Jilid VIII (Jakarta: Departemen Agama RI, 2009), 301.

${ }^{24} \mathrm{Jalāl}$ al-Dīn al-Maḥallī dan Jalāl al-Dīn al-Suyūtī, Tafsìr al-Qư'ān al-'Aẓīm (Bandung: Sinar Baru Algesindo, 2011), 370.
} 
perasaan sedih memberitahukan kepada Ismail tentang perintah Allah yang disampaikan kepadanya melalui mimpi. Dia meminta pendapat anaknya mengenai perintah itu. Al-Qurțubī menjelaskan, bahwa:

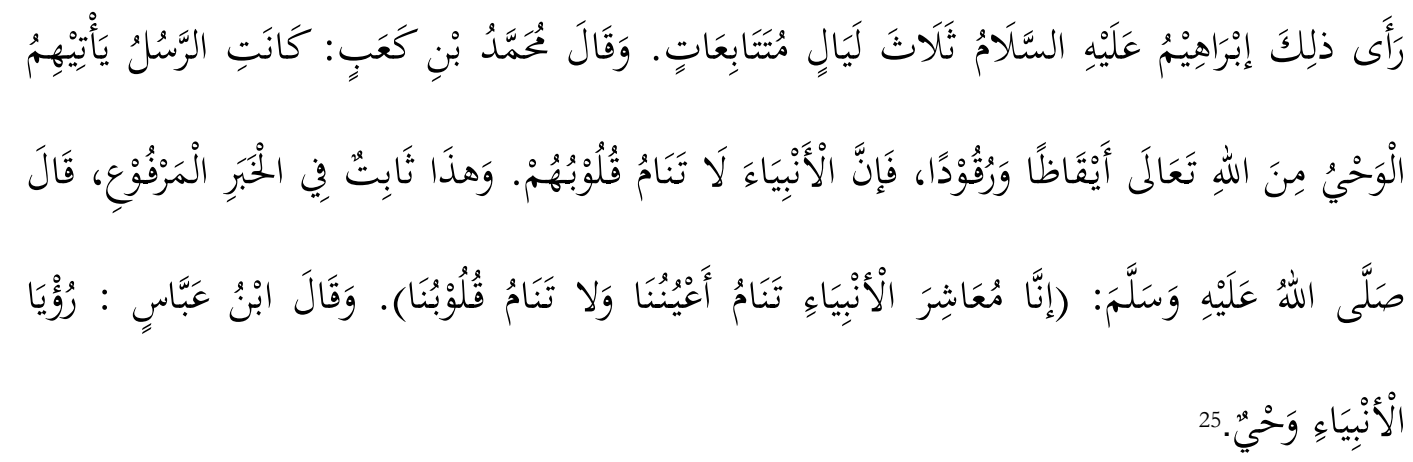

Artinya:

Ibrahim a.s memimpikannya tiga malam berturut-turut. Muhammad bin Ka'ab berpendapat: seorang rasul didatangi wahyu dari Allah SWT baik dalam keadaan terjaga maupun dalam keadaan tidur, karena sesungguhnya para nabi hatinya tidak tidur. Hal ini disebutkan dalam hadis yang marfǘ, Rasulullah saw bersabda: (sesungguhnya istirahatnya para nabi adalah tertidurnya mata kami, namun hati kami tidak tertidur). Menurut Ibnu Abbas, mimpi para nabi adalah wahyu.

Ibnu 'Ādil al-Ḥanbalī menjelaskan bahwa sebelum Ibrahim diberi kabar gembira tentang seorang anak laki-laki, Ia pernah berkata: dia (anakku) akan jadi sembelihan untuk Allah. Maka dalam mimpi itu dikatakan kepadanya "sungguh kamu telah bernazar sebuah nazar maka penuhilah nazarmu itu”, maka ketika pagi Ibrahim berkata, "wahai anakku sesungguhnya saya melihat dalam mimpiku bahwasanya aku menyembelihmu". Suatu pendapat, Ibrahim telah melihat pada malam renungan dalam tidurnya seseorang berkata: sesungguhnya Allah memerintahkanmu untuk menyembelih anakmu. Ketika pagi, Ibrahim memikirkan mimpi itu sampai waktu sore, apakah mimpi ini dari Allah atau dari setan? oleh karena itu, disebut hari renungan (berpikir). Pada malam selanjutnya dia melihat hal itu lagi, dan dia mengetahui bahwa itu dari Allah SWT maka dinamakanlah hari arafah (mengetahui). Kemudian dia melihat hal itu lagi pada malam ketiga lalu mengupayakan untuk berkurban maka dinamakanlah hari kurban. Pendapat ini dipegang kebanyakan mufasir. Ini menunjukkan bahwa Ibrahim melihat dalam mimpi sesuatu yang diwajibkan kepadanya, yakni menyembelih putranya. ${ }^{26}$

${ }^{25} \mathrm{Al}-\mathrm{Qurțubī,} \mathrm{Tafsìr} \mathrm{al-Qurtubì,} 234$.

${ }^{26} \mathrm{Ibnu}$ 'Ādil al-Ḥanbalī, al-Bābu fì 'Ulūm al-Kitāb, Juz XVI (Bairut: Dar al-Kitab al-Ilmiyah, 1998), 330. 
QS al-Ṣaffāt/37: 102 menggunakan bentuk kata kerja mudārí (masa kini dan akan datang) pada kata-kata أَذَبَكُكَ (saya melihat) dan (saya menyembelihmu), demikian juga kata تُؤمَرْ (diperintahkan). Ini mengisyaratkan bahwa apa yang Ibrahim lihat dalam mimpi seakan-akan masih terlihat hingga saat penyampaiannya. Sedang penggunaan bentuk tersebut pada kata "menyembelihmu" untuk mengisyaratkan bahwa perintah Allah yang dikandung mimpi itu belum selesai dilaksanakan, tetapi hendaknya segera dilaksanakan. Karena itu jawaban sang anak menggunakan kata kerja masa kini juga untuk mengisyaratkan bahwa ia siap dan hendaknya sang ayah melaksanakan perintah Allah yang sedang maupun yang akan diterimanya. ${ }^{27}$

\section{Episode III (Lulus Ujian)}

Dijelaskan Ka'ab dalam al-Qurțubī, bahwa:

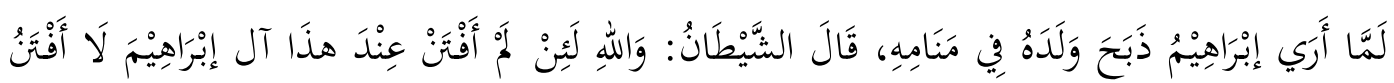

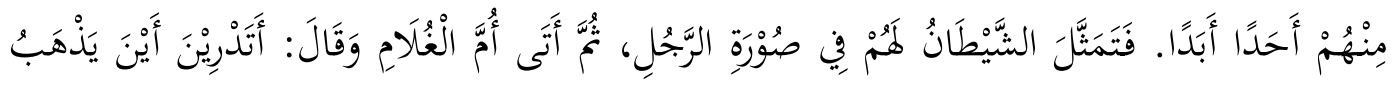

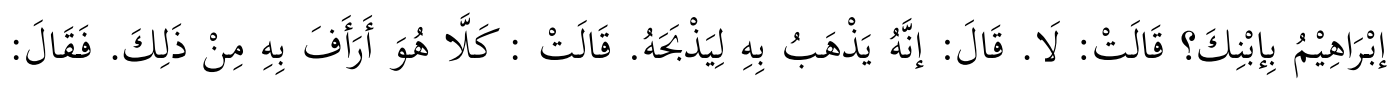

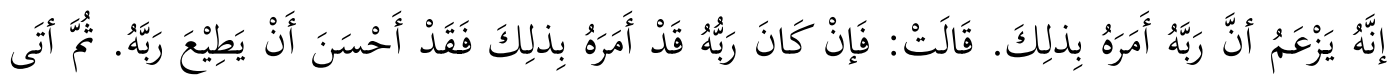

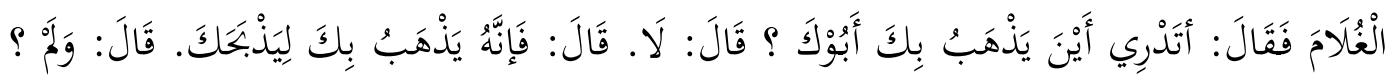

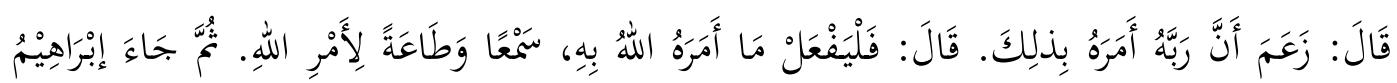

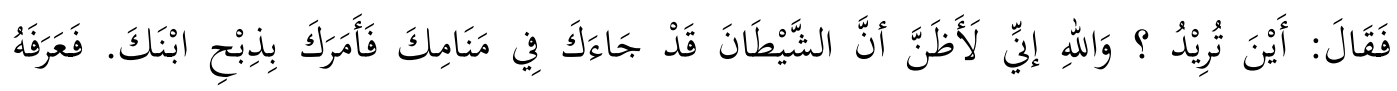

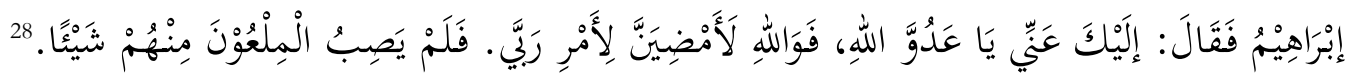
Artinya:

Ketika Ibrahim melihat menyembelih anaknya dalam mimpinya, setan berkata: demi Allah, jika saya tidak mampu mencerai-beraikan keluarga Ibrahim karena peristiwa ini maka saya tidak akan mencerai-beraikan seorang pun dari mereka selamanya. Setan

${ }^{27}$ M. Quraish Shihab, Tafsir Al-Mishbab: Pesan, Kesan, dan Keserasian Al-Quran, Volume 12 Jakarta: Lentera Hati, 2009), 62.

${ }^{28} \mathrm{Al}-\mathrm{Qurțubī}$, Tafsir al-Qurțubī, 235-236. 
berubah wujud kepada mereka dalam bentuk (menyerupai) seorang laki-laki, kemudian mendatangi ibu sang anak (Hajar) lalu berkata: apakah kamu tidak mengetahui ke mana Ibrahim pergi membawa anakmu? Dia (Hajar) menjawab: Tidak. Setan berkata: sesungguhnya dia pergi membawa anakmu untuk menyembelihnya. Hajar bertanya: apakah dia sungguh tidak kasihan melakukan hal tersebut? Setan menjawab: Sesungguhnya dia berdalih (beralasan dengan meyakini) bahwa Tuhannya yang memerintahkan hal tersebut. Hajar berkata: Jika Tuhan yang sungguh memerintahkan hal tersebut maka lebih baik untuk taat kepada Tuhan. Kemudian setan mendatangi sang anak (Ismail) dan bertanya: apakah kamu tidak mengetahui ke mana ayahmu membawamu? Ismail menjawab: Tidak. Setan berkata: sesungguhnya dia membawamu untuk menyembelihmu. Ismail bertanya: Lalu (memangnya) mengapa? Setan menjawab: dia berdalih bahwa Tuhannya memerintahkan hal tersebut. Ismail berkata: Maka biarkanlah dia mengerjakan apa yang diperintahkan Allah kepadanya, saya mendengar dan patuh kepada perintah Allah. Kemudian setan mendatangi Ibrahim lalu berkata: Kamu mau ke mana? Demi Allah, sungguh saya menganggap bahwa setan telah mendatangimu dalam mimpi kemudian memerintahkanmu untuk menyembelih anakmu. Ibrahim mengetahui (dia adalah setan) kemudian berkata: kamu yang datang kepadaku wahai musuh Allah, demi Allah saya akan lebih mendahulukan perintah Tuhanku. Setan tedak berhasil mempengaruhi mereka sedikitpun.

Dilanjutkan oleh Ibnu Abbas dalam al-Qurțubī, ketika Ibrahim dan Ismail berjalan menuju ke tempat penyembelihan,

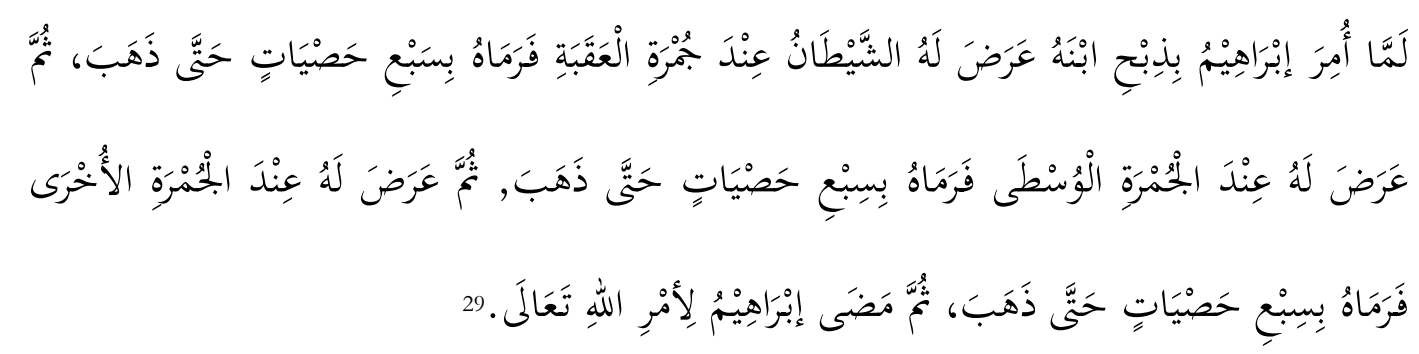

Artinya:

Tatkala Ibrahim diperintahkan untuk menyembelih anaknya, setan menggodanya pada jumrah aqabah maka Ibrahim melemparnya dengan batu tujuh kali hingga setan pergi. Kemudian datang lagi setan menggodanya pada jumrah wusțā maka Ibrahim melemparinya dengan batu tujuh kali hingga setan pergi. Kemudian datang lagi setan

${ }^{29} \mathrm{Al}$-Qurțubī, Tafsir al-Qurtubì, 236. 
menggodanya pada jumrah yang lain maka Ibrahim melemparinya lagi dengan batu tujuh kali hingga setan pergi, kemudian Ibrahim melaksanakan perintah Allah SWT.

Sejarah yang dipaparkan tersebut membuktikan keberhasilan Ibrahim lulus dari ujian berat yang diberikan Allah SW'T kepadanya, sebagaimana disebutkan dalam QS al-Ṣaffāt/37: 103-105.

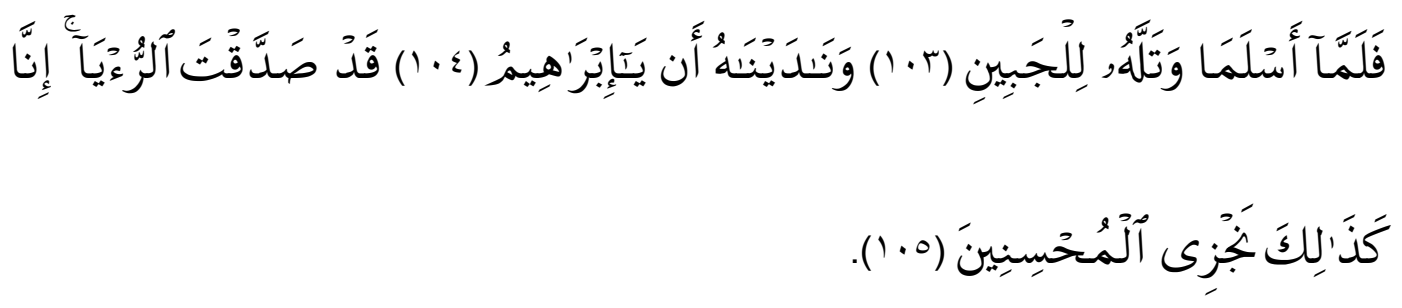

Terjemahnya:

103. Tatkala keduanya telah berserah diri dan Ibrahim membaringkan anaknya atas pelipis(nya), (nyatalah kesabaran keduanya).

104. Dan kami panggillah dia: "Hai Ibrahim!

105. Sesungguhnya kamu Telah membenarkan mimpi itu”, sesungguhnya demikianlah kami memberi balasan kepada orang-orang yang berbuat baik. ${ }^{30}$

Dipaparkan dalam Tafsìr al-Marāgì, bahwa tatkala Ibrahim dan Ismail telah berserah diri untuk tunduk kepada perintah Allah, Ibrahim menelungkupkan wajah anaknya ${ }^{31}$ dengan memberi isyarat kepadanya, sehingga ia tidak melihat wajah anaknya itu yang bisa mengakibatkan rasa kasihan kepadanya. Diriwayatkan dari Mujahid bahwa Ismail berkata kepada ayahnya: "Janganlah engkau menyembelihku sedang engkau melihat kepada wajahku. Boleh jadi engkau kasihan kepadaku sehingga tidak tega kepadaku. Ikatlah tangan dan leherku, kemudian hadapkan wajahku ke tanah.” Ibrahim pun menuruti permintaan anaknya. ${ }^{32}$

Dijelaskan dalam Tafsir Jalālayn, فَلَمَّا أَنْلَمَا (tatkala keduanya telah berserah diri) artinya tunduk dan patuh kepada perintah Allah SWT. و نَلَّهُ لِلْجبِيْنِن (dan Ibrahim membaringkan anaknya atas pelipisnya) Ismail dibaringkan pada salah satu pelipisnya, kemudian

\footnotetext{
${ }^{30}$ Departemen Agama RI, Al-Qur'an dan Terjemahnya, 641.

${ }^{31}$ Ismail waktu itu sedang menggunakan baju gamis (panjang) putih. Dia berkata kepada ayahnya, "wahai ayahku, tidak ada kain untuk mengafaniku kecuali gamisku ini, maka lepaskanlah supaya kamu dapat mengafaniku dengan gamisku." Ibrahim mulai menanggalkan gamis itu. Lihat Departemen Agama RI, Al-Qur'an dan Tafsirnya, 302.

${ }^{32}$ Aḥmad Musțāfa al-Marāgī, Tafüir al-Marāğì, 74.
} 
Ibrahim menggorokkan pisau ke leher Ismail, akan tetapi berkat kekuasaan Allah pisau itu tidak mempan sedikitpun. Ketika itu, dipanggillah Ibrahim oleh Allah melalui perantaraan malaikat: "Hai Ibrahim, sungguh engkau telah membenarkan mimpi menyangkut penyembelihan anakmu dan engkau telah melaksanakan sekuat kemampuanmu". ${ }^{33}$ Penyembelihan Ismail oleh Ibrahim yang diurungkan karena seruan Allah yang datang mendadak itu digantikan dengan seekor kibas (domba) yang telah tersedia di hadapan Ibrahim saat dia mengangkat pisau yang nyaris memotong leher Ismail. Peristiwa ini pun menjadi dasar dilakukannya kurban pada setiap hari raya Idul Adha. ${ }^{34}$

\section{Episode IV (Penghargaan)}

Suatu ujian yang nyata (berat) bagi seseorang yang sangat mengharapkan keturunan, setelah usia 86 tahun keinginan itu baru dikabulkan Allah. Namun, ketika itu anak satusatunya tersebut justru diperintahkan Allah melalui mimpi untuk menyembelihnya. Perintah tersebut dilaksanakan dengan tidak ada keraguan sedikitpun, baik pada Ibrahim sebagai ayah maupun Ismail sebagai anak. Lantaran ketaatan, kecintaan, dan ketawakalan keduanya kepada Allah (aslama), maka pantaslah jika Allah memberi penghargaan padanya predikat "almubsinin" (orang yang dalam hidupnya berbuat kebajikan). ${ }^{35}$

Bentuk penghargaan lainnya disebutkan dalam QS al-Ṣaffāt/37: 106-108.

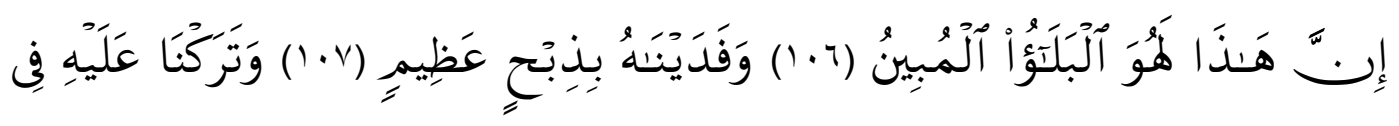

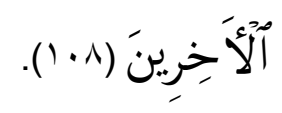

Terjemahnya:

106. Sesungguhnya ini benar-benar suatu ujian yang nyata.

107. Dan kami tebus anak itu dengan seekor sembelihan yang besar.

108. Kami abadikan untuk Ibrahim itu (pujian yang baik) di kalangan orangorang yang datang kemudian. ${ }^{36}$

\footnotetext{
33Jalāl al-Dīn al-Maḥallī dan Jalāl al-Dīn al-Suyūtī, Tafsìr al-Qur'àn al-'Azìm, 370.

${ }^{34}$ Ibnu Kașīr, Tafsìr al-Qur'ān al-'Ażìm, 23.

${ }^{35}$ Abdul Malik Karim Amrullah, Tafsir al-Azhar, 144.

36Departemen Agama RI, Al-Qur'an dan Terjemahnya, 641-642.
} 
Menurut tafsir Jalālayn, "وَفَفَ يْنَاهُ" (dan kami tebus anak itu), yaitu anak yang diperintahkan untuk disembelih (Ismail), “" (dengan seekor sembelihan) yakni dengan

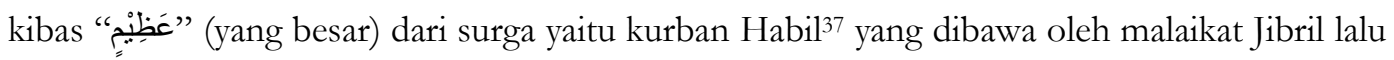
Ibrahim menyembelihnya seraya membaca Takbir. ${ }^{38}$ Menurut al-Marāgī, wa taraknā 'alaibi fì al-äkbirin (dan kami kekalkan untuk Ibrahim pujian yang baik di kalangan manusia di dunia), sehingga dia menjadi orang yang dicintai dikalangan semua orang dari agama dan aliran mana pun. Umat Yahudi, Nasrani, dan Islam mengagungkan dan menghormatinya. Mereka mengatakan: "Sesungguhnya kami menganut agama Ibrahim, bapak kami". Hal itu merupakan pengabulan atas doa Ibrahim:

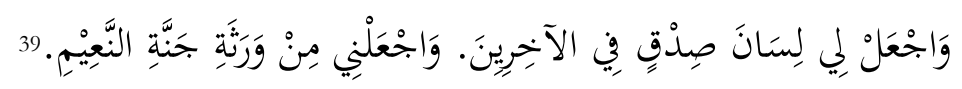

Artinya:

Jadikanlah bagiku perkataan yang benar bagi kaum setelahku. Dan jadikanlah saya termasuk pewaris surga yang megah.

Doa tersebut memiliki korelasi dengan hadis Nabi saw. dari Zaid bin Arqam berkata: Para sahabat Rasulullah saw bertanya: "Ada apa dengan kurban ini?" Rasulullah saw menjawab: "Sunnah bapakmu Ibrahim" (HR. Ibnu Majah). ${ }^{40}$ Ini mengindikasikan bahwa pengsyariatan ibadah kurban yang dilakukan sekali setahun merupakan bentuk taraknā alaihi fi al-äkhirìn. Ibadah kurban sebagai pengingat terhadap sejarah Ibrahim dan Ismail agar dapat dipuji dan diteladani. Sungguh besar penghargaan Allah SWT terhadap hambanya yang sabar, taat, dan tawakal kepada-Nya.

\footnotetext{
${ }^{37}$ Anak Adam a.s. saat diperintahkan oleh Allah berkurban bersama Qabil untuk menentukan orang yang menikahi Iqlima. Lihat QS al-Maidah/5: 27.

${ }^{38}$ Jalāl al-Dīn al-Maḥallī dan Jalāl al-Dīn al-Suyūtī, Tafsìr al-Qur'àn al-'Ażìm, 370. Diriwayatkan bahwasanya ketika Ibrahim telah melakukan sembelihan, Jibril berkata: Allähu akbar Allähu akbar. Lalu Ismail berkata: Là Iläha illalläh. Kemudian Ibrahim berkata: Allähu akbar wa al-hamdu lilläh. Lihat alQurțubī, Tafsir al-Qurtubì, 236.

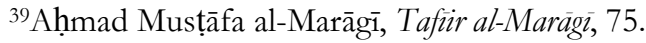

40Ibnu Mājah, Sunan Ibn Mäjah, Juz II (Bairut: Dar al-Fikr, 1997), 1045.
} 


\section{NILAI-NILAI TARBIYAH DALAM IBADAH KURBAN}

\section{Nilai Pendidikan Keimanan}

Iman merupakan kepercayaan yang terhujam ke dalam hati dengan penuh keyakinan, tak ada perasaan syak (ragu-ragu) serta mempengaruhi orientasi kehidupan, sikap dan aktivitas keseharian. ${ }^{41}$ Menurut al-Gazali, iman adalah mengucapkan dengan lidah, mengakui benarnya dengan hati dan mengamalkan dengan anggota badan. ${ }^{42}$ Dipertegas Assegaf bahwa iman berarti pengetahuan (knowledge), percaya (belief, faith) dan yakin tanpa bayangan keraguan (to be convinced beyond the least shadow of doubt). Dengan demikian, iman adalah kepercayaan yang teguh yang timbul akibat pengetahuan dan keyakinan. Iman ini yang menuntun seseorang untuk bersikap taat, tunduk, patuh, pasrah, dan takwa kepada Allah SWT. Orang dengan karakteristik seperti ini disebut sebagai muslim. ${ }^{43}$

Berdasarkan pengertian iman tersebut, bila dikaitkan dengan sejarah ibadah kurban, sungguh keimanan yang begitu luar biasa kokoh diperlihatkan Ibrahim dan Ismail. Buah dari keimanan mereka adalah melaksanakan perintah penyembelihan dari Allah SWT. Mereka siap untuk melakukan apa saja yang diperintahkan Allah, termasuk mengorbankan orang yang disayangi bahkan nyawanya sekalipun. Dengan demikian, dapat diketahui bahwa suatu ibadah akan mudah terlaksana bila dilandasi dengan iman yang kuat. Sejauh mana ketaatanmu, maka sejauh itu pula lah keimananmu. Jangan tanyakan posisimu di sisi Allah, tetapi ketahui di mana posisi Allah di dirimu. Di manapun posisi Allah di dirimu, maka di situ pula lah Allah memposisikanmu di sisinya.

\section{Nilai Pendidikan Akhlak}

Akhlak adalah sifat yang tertanam dalam jiwa yang menimbulkan perbuatanperbuatan dengan mudah tanpa memerlukan pemikiran dan pertimbangan. ${ }^{44}$ Menurut Rāgib al-Iṣfahānī, akhlak merupakan suatu daya yang diketahui dengan akal atau bagi dayah gariziyyah (tabiat), dalam artian suatu keadaan yang diupayakan menuju terbentuknya sesuatu, atau berbagai upaya manusia dalam melatih kemampuan-kemampuannya melalui pembiasaan. ${ }^{45}$ Sehingga, akhlak dapat dimaknai sebagai keadaan jiwa manusia yang menjadi sumber lahirnya suatu tindakan secara spontan.

\footnotetext{
${ }^{41}$ Yusuf al-Qaradawi, Al-Iman wal Hayat. Terj. Jazirotul Islamiyah, Merasakan Kehadiran Tuban (Yogyakarta: Mitra Pustaka, 2007), 27.

${ }^{42}$ Yunahar Ilyas, Kuliah Aqidah Islam (Yogyakarta: LPPI, 2002), 6.

${ }^{43} \mathrm{Abd}$. Rachman Assegaf, Filsafat Pendidikan Islam: Paradigma Baru Pendidikan Hadhari Berbasis IntegratifInterkonektif (Jakarta: Rajawali Pers, 2011), 38.

${ }^{44}$ Didiek Ahmad Supadie, et. al., Pengantar Studi Islam (Jakarta: Rajawali Pers, 2011), 216.

45 Amril, Akblak Tasawuf: Meretas Jalan Menuju Akblak. Mulia (Bandung: Refika Aditama, 2015), 1-2.
} 
Nilai pendidikan akhlak yang terkandung dalam sejarah ibadah kurban, dapat dilihat dari beberapa sikap Ibrahim sekeluarga dalam merespons perintah penyembelihan dari Allah SWTT, yaitu: Doa Ibrahim kepada Allah SWTT. agar dikaruniakan anak yang saleh, sikap Ismail setelah mendengarkan perintah penyembelihan dari Allah SWT, kepatuhan Hajar kepada Allah dan suaminya ketika digoda oleh setan untuk menghentikan Ibrahim melakukan penyembelihan terhadap anaknya.

\section{Nilai Pendidikan Kesabaran}

Hakikat sabar adalah pengendalian diri untuk tidak berbuat keji dan dosa, mampu menaati perintah Allah, memegang teguh akidah Islam dan mampu tabah untuk tidak mengeluh atas musibah apapun yang menimpa. Kesabaran bukanlah kepasrahan terhadap segala sesuatu yang sulit untuk dilaksanakan atau dicapai, kesabaran juga tidak pernah menutup potensi manusia untuk berusaha mengeluarkan segala kemampuan yang dia miliki, melainkan membuat manusia untuk tetap optimis dan mempunyai jiwa yang giat berusaha tanpa mengenal yang namanya putus asa. ${ }^{46} \mathrm{Jadi}$, sabar adalah ketabahan hati seseorang dalam menerima dan menghadapi berbagai ujian dari Allah.

Nilai pendidikan kesabaran yang dicontohkan dalam sejarah ibadah kurban adalah ketabahan hati Ibrahim sekeluarga dalam menerima ujian dari Allah berupa perintah penyembelihan anaknya. Sejarah tersebut mengindikasikan bahwa sabar itu hanya berlaku untuk ketetapan Allah yang tidak sesuai dengan keinginan kita. Orang yang sabar bukan berarti selalu menunggu dengan berdiam diri tanpa langkah yang pasti, melainkan selalu aktif dalam merancang segala tindakannya dan cenderung tidak tergesa-gesa dalam mengambil sikap dan keputusan. Sikap pasif bukanlah sifatnya para penyabar, karena sifat pasif tidak pernah menghasilkan prestasi dan kebaikan. Orang yang sabar kuat jiwanya dalam menghadapi masalah sehingga jauh dari penyakit jiwa.

\section{Nilai Pendidikan Tawakal}

Tawakal adalah membebaskan hati dari ketergantungan kepada selain Allah SWT dan menyerahkan segala keputusan hanya kepada-Nya. Tawakal menjadi landasan atau tumpuan akhir dalam suatu usaha/perjuangan. Meskipun tawakal diartikan sebagai penyerahan diri sepenuhnya kepada Allah SWT, namun tidak berarti orang yang bertawakal harus meninggalkan semua usaha, sehingga kekeliruan besar bila orang yang menganggap tawakal dengan memasrahkan segalanya kepada Allah SW'T tanpa diiringi dengan usaha

46Wahid Ahmadi dan Rachmi Hamidawati, Risalah Akblak: Panduan Perilaku Muslim Modern (Solo: Era Intermedia, 2004), 85. 
maksimal. ${ }^{47}$ Jadi, tawakal adalah penyerahan secara total kepada Allah SWT. atas segala perkara dari ikhtiar (usaha) yang telah dilakukan.

Nilai pendidikan tawakal yang terkandung dalam sejarah ibadah kurban ditunjukkan ketika Ibrahim bersiap menyembelih Ismail dan Ismail berada pada posisi bersiap untuk disembelih, keduanya berserah diri kepada Allah SWT, sebagaimana disebutkan dalam QS alSaffāt/37: 103. Ada dua hal menarik dalam ayat ini, yaitu: (1) Allah menempatkan kata lebih awal dari kata تلك للجبين" adalah wau li aljam‘i, bukan wau li al-tartibi, ini menunjukkan bahwa tawakal itu bukan akhir dari ikhtiar saja, tetapi mengawali ikhtiar, menemani ikhtiar, dan mengakhiri ikhtiar, sehingga tawakal itu dapat menjadi penyemangat kekuatan lahiriah dan pengokoh kekuatan batiniah. Orang tawakal tinggi semangat kerjanya, tidak mudah putus asa dan jauh dari rasa kecewa.

\section{Nilai Pendidikan Keikhlasan}

Ikhlas merupakan kondisi hati yang menghasilkan perbuatan semata-mata karena Allah SWT. Al-Tusturi pernah ditanya: "Apakah sesuatu yang paling berat di rasakan oleh hawa nafsu?" Dia menjawab: "Ikhlas, karena sesungguhnya hawa nafsu tidak punya peran di dalamnya. Ikhlas akan melepaskan semua peran hawa nafsu". ${ }^{48}$ Sejalan dengan pendapat Sentanu, bahwa di dalam diri kita terdapat dua zona, yaitu zona nafsu dan zona ikhlas. Zona nafsu merupakan wilayah yang dipenuhi dengan keinginan namun terasa menyesakkan dada. Zona ini diselimuti oleh energi rendah karena yang ada di dalamnya adalah perasaan negatif, cemas, takut, keluh kesah, dan amarah. Sedangkan zona ikhlas adalah zona yang bebas hambatan, terasa lapang di hati. Energi yang menyelimuti zona ikhlas adalah berbagai perasaan positif yang berenergi tinggi seperti rasa syukur, sabar, fokus, tenang, dan senang.

Nilai pendidikan keikhlasan yang ditunjukkan dalam sejarah ibadah kurban adalah keikhlasan Ibrahim sekeluarga dalam menjalankan perintah Allah. Ibrahim dan Hajar ikhlas mengurbankan anaknya, Ismail ikhlas disembelih sebagai kurban kepada Allah SWT. Hal ini tentu lahir karena kecintaan hamba terhadap Tuhannya.49 Jadi, keikhlasan dapat muncul bila ada cinta atau kasih sayang. Sehingga penting bagi pendidik untuk menyayangi peserta didiknya demi memunculkan keikhlasan dalam mendidik. Keikhlasan dalam mendidik dapat mendatangkan berkah dari Allah SWT. Selain itu, rasa sayang pada peserta didik akan membuat pendidik lebih bertanggung jawab atas pencapaian peserta didik.

\footnotetext{
${ }^{47}$ Amin Syukur, Tasawnf Bagi Orang Awam: Menjawab Problem Kebidupan (Yogyakarta: Pustaka Pelajar, 2006), 97.

${ }^{48}$ Muhammad Gatot Aryo, Keajaiban Ikhlas: Cara Meraih Kesuksesan dan Kebahagiaan Hidup Dunia Akbirat (Jakarta: Coretan Books Publishing, 2007), 16.

${ }^{49}$ Amin Syukur, Tasawuf Bagi Orang Awam, 97.
} 


\section{Nilai Pendidikan Demokratis}

Demokrasi dalam pendidikan dimaknai oleh Sutari Imam Barnadib sebagai sifat kepemimpinan orang tua dalam mendidik yang mengandung unsur kewibawaan, tetapi bukan otoriter, kepemimpinan ini disesuaikan dengan taraf perkembangan anak dengan cita-cita, minat, kecakapan, dan pengalamannya. Anak ditempatkan pada tempat yang semestinya, yang mempunyai kebebasan untuk berinisiatif dan aktif. Di samping itu, orang tua memberikan pertimbangan dan pendapat kepada anak, sehingga anak mempunyai sikap terbuka dan bersedia mendengarkan pendapat orang lain karena anak sudah terbiasa menghargai hak dari anggota keluarga di rumah. ${ }^{50}$

Hal serupa diungkapkan Wiryo Kusuma, bahwa demokrasi dalam lingkup pendidikan adalah pengakuan terhadap individu peserta didik sesuai dengan harkat dan martabat peserta didik itu sendiri, karena demokrasi adalah alami dan manusiawi. Ini berarti bahwa pihak-pihak yang terlibat dalam proses pendidikan harus mengakui dan menghargai kemampuan dan karakteristik individu peserta didik tanpa ada unsur paksaan atau mencetak peserta didik yang tidak sesuai dengan harkatnya. ${ }^{51}$

Nilai pendidikan demokratis yang dicontohkan Ibrahim dalam sejarah ibadah kurban terlihat pada cara menyampaikan perintah Allah SWT. yang diperolehnya melalui mimpi, sebagaimana disebutkan dalam QS al-Ṣaffāt/37: 102. Ibrahim tidak mengatakan "saya ingin menyembelihmu karena perintah Allah", akan tetapi mengatakan "saya diperintahkan Allah menyembelihmu, bagaimana pendapatmu mengenai perintah itu?" Kalimat dalam pertanyaan ini menunjukkan keyakinan Ibrahim akan kewajiban melaksanakan penyembelihan, namun Ibrahim masih menanyakan pendapat Ismail mengenai penyembelihan itu. Suatu sikap demokratis yang perlu diteladani dalam mendidik anak atau peserta didik.

\section{Nilai Pendidikan Dialogis}

Dialog secara bahasa berarti percakapan, artinya percakapan untuk bertukar pikiran (diskusi). Menurut Ruel L. Howe, dialog adalah suatu percakapan antara dua orang atau lebih di mana terdapat pertukaran arti atau nilai antara keduanya sebagai ganti halangan yang biasanya menggagalkan relasi kedua belah pihak. Ini berarti bahwa salah satu pihak tidak boleh mencoba hanya mengemukakan pendapatnya sendiri kepada pihak lain, sehingga ciri komunikasi dialogal adalah adanya respon (umpan balik) dari relasi komunikasi demi mengungkapkan pendapatnya. Jadi, tujuan dialog bukanlah mencari kebenaran atau membuat

\footnotetext{
${ }^{50}$ Sutari Imam Barnadib, Pengantar Ilmu Pendidikan Sistematis (Yogyakarta: Andi Ofset 2007), 125. ${ }^{51}$ Iskandar Wiryo Kusuma, Demokrasi Belajar dan Pembelajaran Ditinjau dari Pengalaman Empirik (Malang: IPTP, 2001), 6.
} 
orang lain mengikuti pendapat kita, tetapi pemahaman tentang sesama (relasi dialog). ${ }^{52}$ Serupa dengan pendapat Ramayulis, bahwa dialog adalah percakapan silih berganti antara dua pihak atau lebih melalui Tanya jawab mengenai suatu topik mengarah kepada suatu tujuan. Kedua belah pihak saling bertukar pendapat tentang suatu perkara tertentu. ${ }^{53}$

Hal ini yang dilakukan Ibrahim dengan memberitahukan Ismail tentang mimpinya agar dapat dipahami oleh Ismail yang masih remaja. Cara berdiskusi ini melatih untuk berargumentasi, ketangguhan dan keteguhan untuk patuh kepada Allah dan orang tuanya. Ini merupakan keberhasilan Ibrahim sebagai ayah dengan kecerdasan akal tetapi lebih mendahulukan wahyu dalam mendidik anaknya. Sikap kepatuhan Ismail dapat dipahami sebagai indikator keberhasilan pendidikan metode dialog.

Pertanyaan Ibrahim "wahai anakku aku melihat dalam mimpiku bahwa aku menyembelihmu, maka bagaimana pendapatmu mengenai mimpi itu?" Ungkapan ini dikuatkan dengan landasan teori bahwa mimpi para Nabi adalah wahyu. Pertanyaan tersebut adalah bentuk ajakan Ibrahim kepada Ismail untuk melaksanakan perintah Allah SWT. Argumentasi Ismail yang mengungkapkan, "wahai ayahku, laksanakanlah perintah Allah" merupakan kecerdasan intelektual dengan dibarengi keterampilan berbicara yang sangat baik. Dia tidak mengatakan "sembelihlah aku", tetapi mengatakan "laksanakanlah perintah Allah". Jawaban ini dapat menjadi obat pelipur lara bagi keduanya dalam menghadapi ujian penyembelihan dari Allah SWT. Argumentasi Ismail dilandaskan kepada kesiapannya untuk melaksanakan perintah Allah SWT dengan cara dan dalam bentuk apapun.

\section{Nilai Pendidikan Sosial}

Sosial berarti segala sesuatu yang berkaitan dengan masyarakat atau secara abstraktif berarti masalah-masalah kemasyarakatan yang menyangkut berbagai fenomena hidup dan kehidupan orang banyak. ${ }^{54}$ Jadi, sosial adalah segala sesuatu yang berkenaan dengan hubungan antar orang atau antar kelompok atau dapat disebut dengan problem kemasyarakatan. Olehnya itu, perlu pendidikan sosial dalam rangka menjaga kestabilan pranata sosial di tengah masyarakat.

Menurut Jalaluddin, Pendidikan sosial adalah usaha untuk membimbing dan mengembangkan potensi peserta didik secara optimal agar mereka dapat berperan serasi

\footnotetext{
${ }^{52}$ Ruel. L. Howe, The Miracle of Dialogue. Terj. Muchtar Karyaman, Keajaiban Dialog (Jakarta: Nusa Indah, 2004), 5.

${ }^{53}$ Ramayulis, Filsafat Pendidikan Islam: Analisis Filosofis Sistem Pendidikan Islam (Jakarta: Kalam Mulia, 2015), 419.

${ }^{54}$ Firdaus M. Yunus, Pendidikan Berbasis Realitas Sosial (Yogyakarta: Logung, 2007), 4.
} 
dengan tuntutan dan kebutuhan masyarakat lingkungannya. ${ }^{55}$ Menurut Abdullah Nasih Ulwan, pendidikan sosial adalah pendidikan anak sejak kecil agar terbiasa menjalankan adab sosial dan dasar-dasar psikis yang bersumber pada aqidah islamiyah agar ia terbiasa dengan pergaulan dan adab yang baik, keseimbangan akal yang matang, dan tindakan yang bijaksana di tengah masyarakat. ${ }^{56}$

Masyarakat pertama dalam kehidupan manusia adalah keluarga (rumah tangga), yang terdiri dari suami, isteri dan anak-anak. Hidup bermasyarakat menimbulkan hak dan kewajiban dikalangan para anggotanya. Hubungan suami, isteri dan anak menimbulkan hak dan kewajiban yang harus dipenuhi masing-masing. ${ }^{57}$ Dikisahkan dalam sejarah ibadah kurban kesadaran Ibrahim sekeluarga atas tugas, peran, dan tanggung jawabnya dalam keluarga sangatlah tinggi. Hal ini tentunya tidak dapat terwujud tanpa upaya dari Ibrahim yang dengan baik melakonkan perannya sebagai kepala rumah tangga, suami, ayah, dan pendidik. Buah dari keberhasilannya itu diberikan balasan oleh Allah berupa keselamatan, predikat mubsin, ${ }^{58}$ serta disyariatkan ibadah kurban untuk meneladani dan memujinya.

Salah satu hikmah dianjurkannya seseorang melihat kurbannya disembelih agar berbaur dengan masyarakat. Hikmah dianjurkannya pembagian daging kurban adalah melatih untuk bersedekah dan merasakan perasaan orang miskin. Namun, ibadah kurban bukan dikotomi antara si miskin dan si kaya, tetapi kesadaran akan tanggung jawabnya masingmasing dalam masyarakat, inilah yang akan membentuk struktur kesatuan sosial.

\section{RELEVANSI NILAI-NILAI TARBIYAH DALAM IBADAH KURBAN DENGAN PEMBELAJARAN PENDIDIKAN FORMAL}

Nilai tarbiyah dalam sejarah ibadah kurban memiliki relevansi dengan desain pembelajaran. Menurut Seels dan Richey dalam Yaumi, design is process of specifying conditions for learning (desain pembelajaran adalah proses untuk menentukan kondisi belajar). Proses tersebut dibagi ke dalam empat domain, yaitu: (1) Instructional systems design, (2) message desain, (3) instructional strategies, (4) learner characteristics. ${ }^{59}$

Instructional systems design (desain sistem pembelajaran) dipahami sebagai prosedur yang terorganisasi yang meliputi langkah-langkah penganalisisan, perancangan,

\footnotetext{
55Jalaluddin, Teologi Pendidikan (Jakarta: Rajawali Press, 2001), 95.

${ }_{56}$ Abdullah Nasih Ulwan, Tarbiyah al-Awläd, Terj. Minzar Hamid, Pendidikan Anak dalam Islam, Jilid II (Jakarta: Pustaka Amani, 2009), 1.

${ }^{57}$ Firdaus M. Yunus, Pendidikan Berbasis Realitas Sosial, 19.

${ }^{58}$ Lihat Q.S. al-Șaffāt/37: 109-110.

${ }^{59}$ Muhammad Yaumi, Prinsip-prinsip Desain Pembelajaran: Disesuaikan dengan Kurikulum 2013 Jakarta: Kencana, 2014), 5-6.
} 
pengembangan, pengaplikasian, dan penilaian pembelajaran. Message desain (desain pesan) merupakan perencanaan untuk memanipulasi bentuk fisik pesan yang mencakup pesan, belajar dan pembelajaran, media, dan desain pesan itu sendiri yang mempengaruhi perhatian, persepsi, dan pemahaman. Instructional strategies (desain strategi pembelajaran) adalah spesifikasi untuk menyeleksi serta mengurutkan peristiwa belajar atau kegiatan belajar dalam suatu pembelajaran. Learner characteristics (karakteristik peserta didik) adalah segi-segi latar belakang pengalaman peserta didik yang berpengaruh terhadap efektivitas proses belajarnya. ${ }^{60}$ Berdasarkan pembagian domain tersebut, dapat dipahami bahwa desain pembelajaran merupakan konsep sistematis dan sistemik yang mengatur dan menentukan kondisi belajar sehingga diperoleh proses pembelajaran yang berkualitas.

Menurut Reiser dan Dampsey dalam Yaumi, bahwa bagaimanapun bentuk dan model suatu desain pembelajaran, karakteristik utamanya harus mencakup enam prinsip, yaitu: (1) Berpusat pada peserta didik, (2) berorientasi tujuan, (3) terfokus pada pengembangan atau perbaikan kinerja peserta didik, (4) mengarahkan hasil yang dapat diukur secara valid dan dapat dipercaya, (5) bersifat empiris, berulang, dan dapat dikoreksi sendiri, (6) hasil usaha yang dilakukan secara bersama (upaya tim). ${ }^{61}$

Memperhatikan definisi dan karakteristik dari desain pembelajaran tersebut, tampak bahwa nilai tarbiyah dalam sejarah ibadah kurban memiliki relevansi dan berimplikasi dalam upaya mendesain suatu pembelajaran. Pembuktiannya dapat dilihat pada deskripsi karakteristik utama desain pembelajaran, sebagai berikut:

\section{Berpusat pada Peserta Didik}

Desain pembelajaran seharusnya mempertimbangkan suatu pendekatan pembelajaran yang berpusat pada peserta didik, dimana peserta didiklah yang mempengaruhi konten, aktivitas, materi, dan fase belajar. Pendekatan ini memosisikan peserta didik pada pusat proses belajar. Pendidik memberikan kesempatan kepada peserta didik untuk belajar secara independen dan saling membantu, serta melatih mereka lebih kreatif dengan memperhatikan keterampilan yang dibutuhkan untuk berbuat secara efektif dalam pembelajaran. ${ }^{62}$ Menurut Dede Rosyada, kurikulum yang diterjemahkan dalam desain pembelajaran harus disusun dengan memperhatikan potensi, tingkat perkembangan, minat,

${ }^{60}$ Muhammad Yaumi, Prinsip-prinsip Desain Pembelajaran, 8.

${ }^{61}$ Muhammad Yaumi, Prinsip-prinsip Desain Pembelajaran, 12.

62Muhammad Yaumi, Prinsip-prinsip Desain Pembelajaran, 12. 
kecerdasan intelektual, emosional dan sosial, spiritual, dan kinestetik peserta didik. Peserta didik menempati posisi sentral, artinya kegiatan pembelajaran berpusat pada peserta didik. ${ }^{63}$

Sejarah ibadah kurban menunjukkan pembelajaran yang pelaksanaannya berpusat pada peserta didik. Hal ini terlihat bila Ismail diposisikan sebagai peserta didik. Perintah penyembelihan datang pada waktu Ismail sampai pada umur sanggup berusaha bersama orang tuanya, suatu pendapat umur Ismail 13 tahun, ada juga yang mengatakan umur Ismail waktu itu 17 tahun. Berapapun umurnya, Ismail pada waktu itu telah balig dan halim (sabar lagi bijaksana). Kesabaran dan kebijaksanaan membutuhkan tingkat pengolahan emosional dan intelektual yang tinggi. Ibrahim sebagai pendidik menyampaikan materi pembelajarannya (perintah penyembelihan) dengan memperhatikan keadaan Ismail sebagai peserta didik. Dia menggunakan metode dialog (diskusi), metode tersebut efektif bila diberikan pada peserta didik yang sudah dapat mengolah kompetensi intelektualnya.

\section{Berorientasi Tujuan}

Tujuan pembelajaran merupakan sesuatu yang ingin dicapai dalam proses pembelajaran berupa peningkatan potensi diri peserta didik. Potensi ini dikenal dengan istilah taksonomi bloom yang mencakup tiga domain; afektif, kognitif, dan psikomotorik. ${ }^{64}$ Menurut Dewantara, tujuan pembelajaran dapat juga diistilahkan sebagai peningkatan kemampuan dalam mengolah diri, yakni; olah pikir, olah rasa, olah raga, dan olah hati.65

Pembelajaran yang berorientasi pada tujuan, ditemukan dalam sejarah ibadah kurban. Hal ini ditunjukkan dalam dua pembelajaran, yaitu:

1. Ibrahim sebagai peserta didik yang dididik langsung oleh Allah SWT.

Tujuan dari pembelajaran ini adalah keimanan Ibrahim kepada Allah SWT. dengan materi perintah penyembelihan anaknya (Ismail) melalui mimpi. Pelaksanaan pembelajaran berlangsung selama tiga malam berturut-turut, sebagaimana terungkap dalam sejarah ibadah kurban bahwa mimpi tersebut berlangsung selama tiga malam berturut-turut.

Mimpi pertama menstimulus pemikiran Ibrahim, sebagai langkah pengembangan domain kognitif. Ketika Ibrahim melihat dalam tidurnya menyembelih anaknya pada malam pertama, keesokan harinya dia memikirkan bahwa apakah mimpi tersebut berasal dari Allah SWT atau dari setan. Mimpi yang sama pada malam kedua berusaha mengembangkan domain afektif Ibrahim. Ibrahim meyakini bahwa ini betul-

${ }^{63}$ Dede Rosyada, Paradigma Pendidikan Demokratis: Sebuah Model Pelibatan Masyarakat dalam Penyelenggaraan Pendidikan (Jakarta: Kencana, 2007), 68.

${ }^{64}$ Dede Rosyada, Paradigma Pendidikan Demokratis, 68.

${ }^{65}$ Muhammad Yaumi, Prinsip-prinsip Desain Pembelajaran, 14. 
betul perintah Allah SWT karena wahyu datang kepada Nabi dalam keadaan apapun, termasuk pada saat tertidur. Mimpi serupa pada malam ketiga semakin meyakinkan hati Ibrahim bahwa perintah penyembelihan tersebut dari Allah SWT dan harus dilaksanakan. Keesokan harinya, Ibrahim melaksanakan perintah Allah SWT tersebut, dan ini mengembangkan domain psikomotorik Ibrahim. Hal tersebut dibuktikan dengan "tallahu li al-jabin" (membaringkan di atas salah satu pelipisnya), kemudian Ibrahim menyembelih domba yang dibawah Jibril sebagai pengganti Ismail dan bertakbir saat akan melakukan penyembelihan. Suatu praktik penyem-belihan hewan yang dianjurkan dalam Islam.

2. Ismail sebagai peserta didik yang dididik oleh Ibrahim

Tujuan pembelajaran ini adalah menjadi anak saleh, ini terlihat pada harapan Ibrahim yang diungkapkannya melalui doa "Rabbi bablì min al-șalihìn" (wahai Tuhanku karuniakanlah kepadaku anak yang saleh). Demi tercapainya tujuan pembelajaran, indikator pembelajaran sangat penting untuk dirumuskan sebelum menetapkan langkah-langkah pembelajaran. Berdasarkan indikator pembelajaran, dapat dilakukan pengembangan materi. Indikator seseorang disebut saleh, di antaranya; sabar, berakhlak mulia, taat kepada Allah, dan patuh kepada orang tua. Dengan demikian peserta didik perlu diberi materi mengenai indikator-indikator tersebut. Berdasarkan sejarah ibadah kurban Ismail telah memenuhi indikator tersebut, berarti Ismail termasuk anak saleh dan pembelajaran yang diterapkan Ibrahim dapat dikatakan berhasil.

Dari penjelasan mengenai kedua pembelajaran tersebut, dapat dipahami bahwa apapun bentuk dan kemampuan yang ingin dikembangkan pada peserta didik, desain pembelajaran harus terfokus pada tujuan pembelajaran. Untuk mempermudah dalam menetapkan materi dan langkah-langkah pembelajaran perlu ditetapkan indikator-indikator pembelajaran yang mengakomodasi tujuan.

\section{Terfokus pada Pengembangan atau Perbaikan Kinerja Peserta Didik}

Desain pembelajaran seharusnya dapat mendorong terciptanya kesesuaian antara lingkungan belajar dengan situasi di mana kemampuan dapat ditunjukkan. Berdasarkan temuan dalam sejarah ibadah kurban, Ibrahim sebagai peserta didik yang dididik langsung oleh Allah SWT dikondisikan berada pada situasi dan lingkungan belajar yang memungkinkan dapat menunjukkan kemampuan hasil belajar yang diperolehnya. Situasi lingkungan belajar Ibrahim dapat digambarkan dalam bagan berikut: 


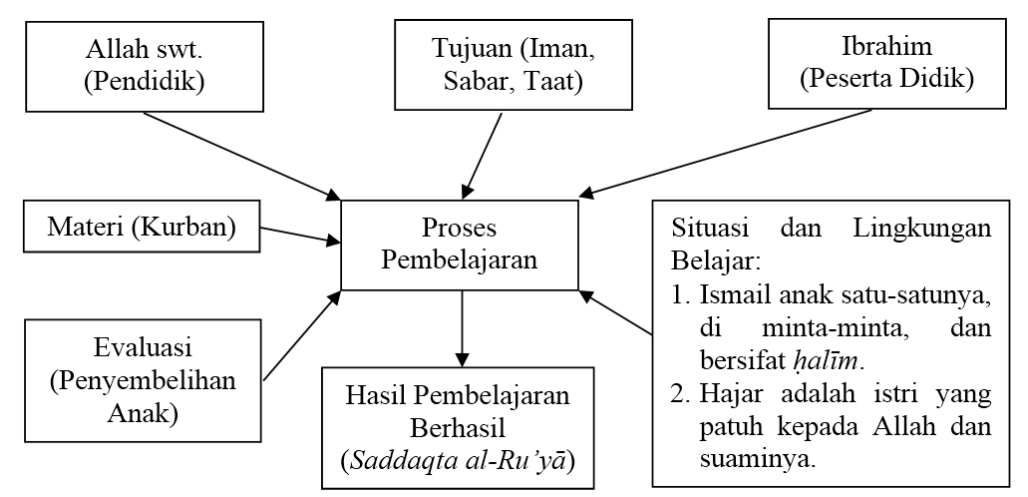

Gambar 1. Situasi dan Lingkungan Belajar Ibrahim dalam Sejarah Ibadah Kurban

Gambar tersebut menjelaskan bahwa Allah SW'T mengondisikan situasi dan lingkungan belajar Ibrahim dapat menunjukkan kemampuan hasil belajar yang diperolehnya. Hal ini karena Ismail anak satu-satunya dan diminta-minta sehingga sangat memungkinkan untuk menguji keimanan, kesabaran, dan ketaatan Ibrahim. Selain itu, Ismail juga anak yang halim, karena ke-halim-an Ismail inilah membuatnya siap untuk disembelih oleh ayahnya. Kesiapan untuk disembelih tersebut merupakan situasi dimana Ibrahim dapat melaksanakan perintah penyembelihan.

Hajar sebagai istri juga menjadi lingkungan belajar yang baik bagi Ibrahim, kepatuhan dan dukungannya kepada suami terlihat saat setan datang ingin memperdayainya untuk mencegah Ibrahim melaksanakan penyembelihan. Setan berkata; "suamimu pergi membawa anakmu untuk menyembelihnya". Hajar menjawab; "Tidakkah dia kasihan kepadanya". Jawaban ini menunjukkan kepatuhan dan dukungan istri kepada suaminya, sebab bila yang dikatakan setan itu benar, bahwa Ibrahim ingin menyembelih Ismail tentu ada sebab yang membuat Ibrahim ingin melakukan hal tersebut. Apapun sebabnya Hajar mendukung keputusan suaminya meskipun harus mengorbankan anak satu-satunya. Selain itu, Hajar juga taat kepada Allah SWT, hal ini terlihat saat setan melanjutkan usahanya memperdayai Hajar. Setan berkata; dia (Ibrahim) berdalih hal tersebut adalah perintah Tuhannya. Hajar menjawab; Jika itu adalah perintah Allah SWT, maka jauh lebih baik melaksanakan perintah-Nya. Sekiranya terjadi pemberontakan oleh Ismail dan Hajar maka tentu pelaksanaan penyembelihan mengalami hambatan. Hasil pembelajaran dengan situasi dan lingkungan belajar yang baik terbukti berhasil, ditandai dengan firman Allah dalam QS al-Ṣaffāt/37: 105 “saddaqta al-ru'ya (kamu telah membenarkan mimpimu) sebagai indikator keimanan, kesabaran, dan ketaatan Ibrahim. 


\section{Mengarahkan Hasil yang Dapat Diukur Secara Valid dan Dapat Dipercaya}

Evaluasi dalam rangka mengukur keberhasilan belajar peserta didik, dilakukan dengan cara tidak langsung. Seorang pendidik yang ingin mengukur tingkat kepandaian peserta didik maka yang diukur bukanlah pandainya, melainkan gejala atau fenomena yang tampak dari kepandaian yang dimiliki peserta didik. Dengan kata lain, yang diukur adalah indikator yang dapat dijadikan kriteria atau tolak ukur seseorang dikatakan pandai. Indikator seseorang yang pandai dapat dirumuskan antara lain: kemampuan untuk bekerja dengan angka-angka, kemampuan untuk menggunakan bahasa dengan baik dan benar, kemampuan untuk menangkap atau mengetahui sesuatu yang baru, kemampuan untuk memahami hubungan antara gejala yang satu dengan gejala yang lainnya, kemampuan untuk berfantasi atau berpikir secara cepat, dan sebagainya. ${ }^{6}$

Menurut Suharsimi Arikunto, sebuah tes dikatakan memiliki validitas bila sesuai dengan kriterium, dalam arti memiliki kesejajaran antara hasil tes tersebut dengan kriterium, ${ }^{67}$ dan suatu tes dapat dikatakan mempunyai taraf kepercayaan (reliabilitas) yang tinggi jika tes tersebut dapat menghasilkan hasil yang tetap. Instrument evaluasi harus valid menyangkut harapan diperolehnya data yang sesuai dengan kenyataan. Jika validitas terkait dengan ketepatan objek atau tidak menyimpangnya data dari kenyataan, artinya bahwa data tersebut benar, maka konsep reliabilitas terkait dengan pemotretan (data evaluasi) berkali-kali. Instrumen yang baik adalah yang dapat dengan ajeg (tetap) memberikan data yang sesuai dengan kenyataan. 68

Bentuk evaluasi yang ditemukan dalam sejarah Ibadah kurban adalah ujian perintah penyembelihan melalui mimpi. Instrumen evaluasi ini ingin mengukur kesalehan Ismail dan keimanan Ibrahim dengan indikator melaksanakan perintah Allah SWT. yang secara akal bertentangan dengan nurani manusia biasa. Tingkat validitas dari instrumen evaluasi ini tinggi, karena memberikan data yang sesuai dengan kenyataan. Tingkat reliabilitasnya pun tinggi karena hasil tes memberikan data yang tetap. Terbukti setan yang datang berulang kali tidak dapat mempengaruhi Ibrahim dan Ismail dalam melaksanakan perintah Allah. Bentuk tindak lanjut dari hasil pembelajaran adalah memberikan penghargaan kepada Ibrahim dengan disyariatkannya ibadah kurban untuk memuji dan mengenang Ibrahim, begitupun Ismail dipuji oleh Allah SWT sebagaimana disebutkan dalam QS Maryam/19: 54-55.

\footnotetext{
${ }^{66}$ Anas Sudijono, Pengantar Evaluasi Pendidikan (Jakarta: PT. RajaGrafindo Persada, 2008), 34. ${ }^{67}$ Suharsimi Arikunto, Dasar-dasar Evaluasi Pendidikan (Jakarta: Bumi Aksara, 2015), 85.

${ }^{68}$ Ibid., h. 100.
} 


\section{Bersifat Empiris, Berulang, dan Dapat Dikoreksi Sendiri}

Data merupakan jantung dari proses desain pembelajaran. Pengumpulan data dimulai sejak analisis awal dan berlanjut hingga sampai pada tahap implementasi. Misalnya, selama fase analisis data dilakukan dengan membandingkan apa yang telah dipahami peserta didik dan apa yang dibutuhkan untuk dipahami. Bimbingan dan umpan balik dari pendidik menentukan ketepatan dan relevansi keterampilan dan pengetahuan untuk diajarkan. Hasil analisis data (penelitian) dan pengalaman pendahuluan mengarahkan penyeleksian strategi dan media pembelajaran. Data yang dikumpulkan selama uji coba formatif membawa implikasi pada revisi-revisi yang diperlukan, kemudian data yang diperoleh di lapangan setelah implementasi memberikan jawaban apakah pembelajaran yang dilaksanakan efektif atau tidak. ${ }^{69}$

Bentuk empiris, berulang, dan koreksi dari pembelajaran yang dilakukan Ibrahim sebagai pendidik dalam sejarah ibadah kurban dapat dilihat pada gambar berikut:

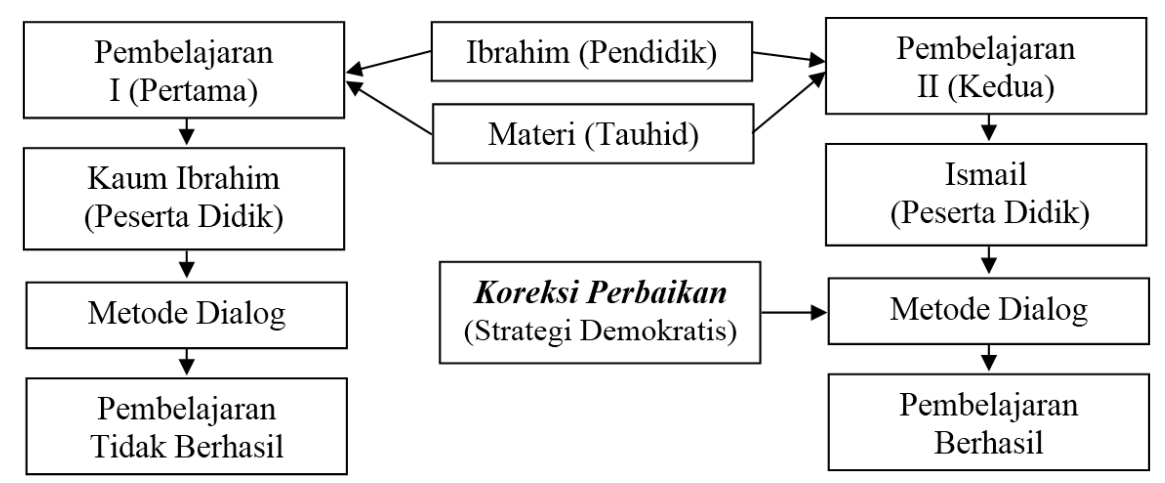

Gambar 2. Koreksi Perbaikan dalam Pembelajaran Metode Dialog Ibrahim

Gambar tersebut menunjukkan desain pembelajaran Ibrahim bersifat empiris, berulang, dan dapat dikoreksi sendiri. Munāsabah (hubungan) sejarah ibadah kurban menurut QS al-Ṣaffāt/37: 100-108 dengan ayat sebelumnya menunjukkan ketidak-suksesan metode dialog yang digunakan Ibrahim kepada kaumnya untuk menerima ajaran tauhid yang disampaikannya. Bahkan Ibrahim harus diselamatkan Allah SWT dari dalam api yang disiapkan oleh kaumnya untuk membakarnya. Pada proses pembelajaran selanjutnya, di mana Ismail sebagai peserta didik terbukti berhasil dengan metode yang sama, namun ada koreksi perbaikan, yakni Ibrahim menggunakan strategi yang lebih demokratis dalam metode dialognya.

${ }^{69}$ Muhammad Yaumi, Prinsip-prinsip Desain Pembelajaran, 16. 


\section{Desain Pembelajaran Adalah Upaya Tim}

Benar bahwa desain pembelajaran dapat dilakukan sendiri, baik dalam menyediakan sumber, kerangka desain, maupun dalam hal penyeleksian dan pengembangan media, materi, dan metode yang digunakan. Akan tetapi, keterlibatan pihak lain dalam suatu tim sangat dibutuhkan karena pada hakikatnya proyek desain merupakan usaha bersama dalam upaya menciptakan suatu produk yang lebih baik. Tidak dapat dipungkiri, proyek yang lebih besar membutuhkan spesialisasi yang lebih besar pula. ${ }^{70}$

Bentuk kerja tim yang ditemukan dalam desain pembelajaran pada sejarah ibadah kurban adalah penggunaan damir mutakallim ma' al-gairih (nahnu $)^{71}$ dalam setiap tindakan yang dilakukan oleh Allah SWT. pada QS al-Ṣaffāt/37: 100-108, ini terlihat pada kata فَبَشَّرْنَاهُ (ayat

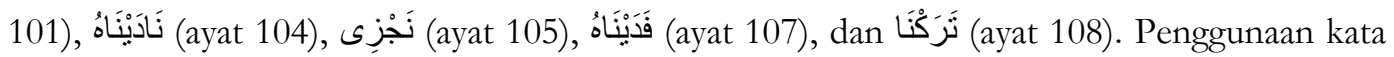
ganti nahnu (kami) untuk perbuatan Allah SWT. dalam Al-Qur'an menunjukkan Allah SWT. melibatkan unsur lain dalam perbuatannya itu, kaitannya dengan ayat ini adalah malaikat. Penggunaan damir nahnu ini juga dapat berimplikasi pada pentingnya kerja sama dalam aktivitas yang mestinya dilakukan secara tim, termasuk dalam mendesain pembelajaran.

Memperhatikan relevansi dari nilai tarbiyah dalam sejarah ibadah kurban dengan karakteristik utama desain pembelajaran, hal ini membuat sejarah ibadah kurban berimplikasi dalam mendesain pembelajaran, sebagaimana ditunjukkan pada gambar berikut:

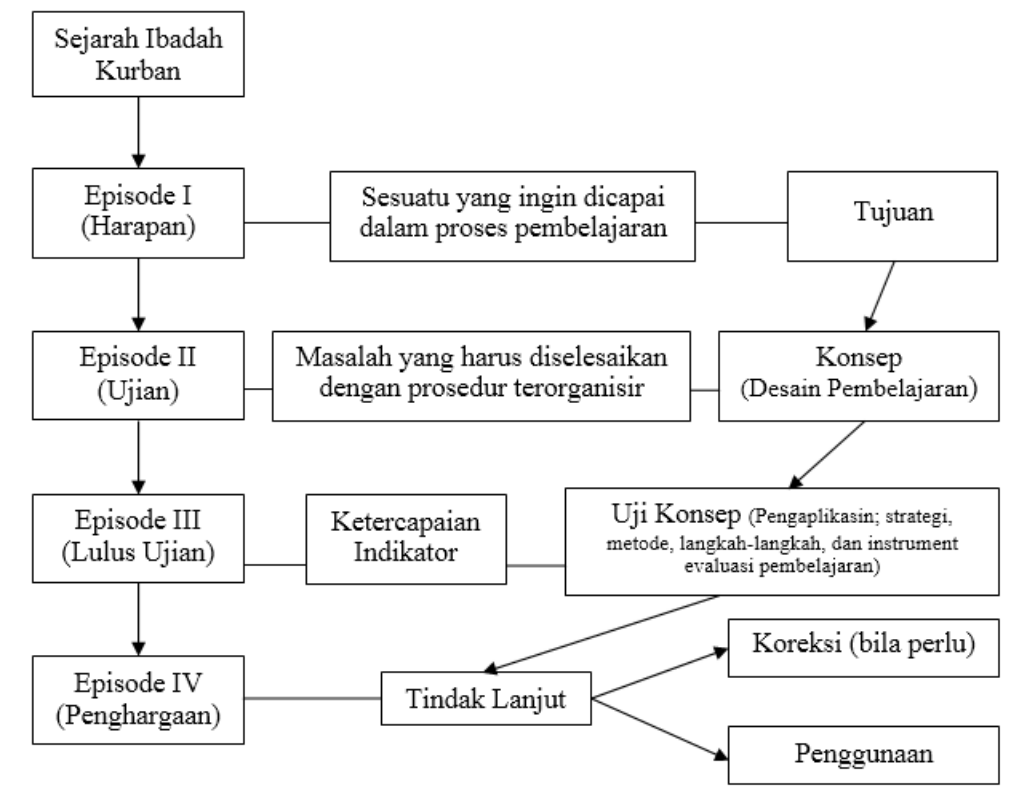

Gambar 3. Tahapan Episode Sejarah Ibadah Kurban dan Penerapannya dalam Desain Pembelajaran

${ }^{70}$ Ibid., h. 17.

${ }^{71}$ Kata ganti orang pertama jamak yang berarti "kami". 
Gambar tersebut menjelaskan bahwa tahapan episode sejarah ibadah kurban memiliki relevansi dengan desain pembelajaran pendidikan formal. Episode I (harapan) merupakan tujuan yang ingin dicapai dalam proses pembelajaran, bagaimana peserta didik yang diharapkan setelah pembelajaran. Desain pembelajaran harus berorienrasi pada tujuan, karena kegiatan tanpa tujuan adalah sesuatu yang sia-sia.

Episode II (ujian) yang dimaksud di sini bukan sekedar evaluasi, akan tetapi penyelesaian masalah. Bagaimana menyelesaikan masalah dalam upaya mencapai tujuan? Penyelesaiannya tentu harus dengan prosedur yang terorganisir. Muncullah sebuah konsep (blueprint) langkah-langkah pembelajaran yang sistematis dan sistemik, mulai dari penganalisisan, perencanaan, pengembangan, dan bentuk evaluasi.

Episode III (lulus ujian) yakni seseorang dikatakan lulus ujian bila memenuhi indikator kelulusan. Begitupun desain pembelajaran dikatakan baik bila telah melalui tahap uji konsep. Untuk menguji desain pembelajaran perlu diterapkan dalam pelaksanaan pembelajaran di kelas. Model, strategi, metode, media dan instrument evaluasi yang telah direncanakan diaplikasikan dalam pembelajaran. Bila Kriteria Ketuntasan Minimum (KKM) terpenuhi, terjadi pengembangan sikap dan keterampilan setelah pembelajaran pada peserta didik, maka desain pembelajaran tersebut baik.

Episode IV (penghargaan) merupakan bentuk apresiasi terhadap pencapaian baik seseorang, dengan kata lain, respons terhadap hasil pembelajaran dalam hal ini tindak lanjut. Bila pembelajaran mencapai tujuan maka desain pembelajaran dapat digunakan, akan tetapi bila sebaliknya, pembelajaran tidak mencapai tujuan maka desain pembelajaran perlu dikoreksi dan direvisi.

Proses pembelajaran yang dilakukan oleh pendidik semestinya melalui tahapantahapan pada episode sejarah ibadah kurban, mulai dari merencanakan, melaksanakan, evaluasi, dan tindak lanjut.

Perencanaan pembelajaran harus memperhatikan kondisi sekolah (peserta didik dan sarana prasarana) sebagaimana dicontohkan Ibrahim saat menyampaikan perintah penyembelihan dari Allah kepada Ismail, dia memperhatikan kondisi Ismail saat itu sebelum menentukan strategi dalam menyampaikan perintah Allah. Begitupun sarana prasarana sebagai penunjang dalam pembelajaran, sehingga menghasilkan lingkungan belajar yang baik dengan fasilitas pendidikan yang memadai.

Pelaksanaan pembelajaran harus profesional, sebagaimana dicontohkan Ibrahim dan Ismail, mereka profesional dalam menjalankan perintah Allah, bentuk keprofesionalan 
tersebut adalah ikhlas, tawakal, dan sabar. Pendidik pun senantiasa harus profesional dalam menjalankan tugas, peran dan tanggung jawabnya sebagai guru.

Evaluasi harus dilakukan untuk mengetahui pencapaian peserta didik dan mengetahui keberhasilan rencana pembelajaran. Instrument evaluasi yang diberikan harus sesuai dengan kriteria yang ingin diukur. Bila yang ingin di ukur adalah perkembangan kognitif, maka instrumen evaluasinya dalam bentuk tes. Bila yang ingin di ukur adalah perkembangan afektif atau psikomotorik peserta didik maka instrumen evaluasi yang digunakan adalah non tes, seperti pengamatan langsung terhadap peserta didik. Pengamatan ini berdasarkan pada dokumen yang berisikan indikator-indikator yang mesti dipenuhi peserta didik dalam bersikap.

Tindak lanjut yang dimaksud di sini bukan hanya koreksi dan revisi terhadap rencana pembelajaran, akan tetapi tindak lanjut harus menstimulus peserta didik untuk lebih termotivasi dan semangat dalam pembelajaran. Sebagaimana bentuk tindak lanjut Allah terhadap Ibrahim dan Ismail yang berhasil dengan baik melalui ujian yang sangat berat. Allah memberi penghargaan kepada Ibrahim dan Ismail dengan disyariatkannya Ibadah kurban untuk memuji dan mengenang keduanya. Begitupun seorang pendidik mestinya memberi tindak lanjut berupa penghargaan (reword), sekalipun itu hanya sekedar pujian atau tepukan tangan. Hal ini akan berpengaruh terhadap semangat dan motivasi belajar peserta didik yang bersangkutan maupun peserta didik lainnya. Hal ini dipraktikkan dalam teori belajar behaveoristik dimana input itu berupa stimulus dan output itu adalah respons. Apa yang dilakukan pendidik adalah stimulus dan apa yang dilakukan peserta didik adalah respons. Bila stimulus ditambah/diperkuat (positive reinforcement) maka respons akan semakin kuat. Begitupun sebaliknya, bila stimulus dikurangi/dihilangkan (negative reinforcement) maka respons akan semakin melemah. ${ }^{72}$

Nilai tarbiyah dalam ibadah kurban juga memiliki relevansi dengan pendidikan karakter dan mengakomodasi seluruh karakter peserta didik yang harus dikembangkan. Relevansi tersebut dapat dilihat pada tabel berikut:

${ }^{72}$ Muhammad Siri Dangnga dan Andi Abd. Muis, Teori Belajar dan Pembelajaran Inovatif (Makassar: SIBUKU, 2015), 68. 
Tabel 1. Akomodasi Nilai Tarbiyah terhadap Pendidikan Karakter

\begin{tabular}{|c|l|l|}
\hline No. & Nilai Tarbiyah & \multicolumn{1}{|c|}{ Nilai Pendidikan Karakter yang Diakomodasi } \\
\hline 1 & Keimanan & Religius \\
\hline 2 & Akhlak & $\begin{array}{l}\text { Jujur, disiplin, kerja keras, kreatif, mandiri, semangat } \\
\text { kebangsaan, cinta tanah air, cinta damai, gemar membaca, } \\
\text { tanggung jawab, dan peduli lingkungan. }\end{array}$ \\
\hline 3 & Kesabaran & Disiplin, cinta damai, dan kerja keras. \\
\hline 4 & Tawakal & Kerja keras dan mandiri. \\
\hline 5 & Keikhlasan & Cinta damai, peduli lingkungan, dan peduli sosial. \\
\hline 7 & Dialogis & Demokratis. \\
\hline 8 & Sosial & $\begin{array}{l}\text { Toleransi, menghargai prestasi, bersahabat/ komunikatif, cinta } \\
\text { damai, peduli lingkungan, dan peduli sosial. }\end{array}$ \\
\hline
\end{tabular}

Tabel tersebut menunjukkan relevansi dan akomodasi nilai-nilai tarbiyah dalam sejarah ibadah kurban terhadap pendidikan karakter. Namun, pendidikan karakter belum sepenuhnya mengakomodasi nilai-nilai tarbiyah dalam sejarah ibadah kurban. Misalnya, ketawakalan dapat mengakomodasi karakter kerja keras, bentuk akomodatifnya adalah kerja keras merupakan ciri dari orang yang bertawakal, namun orang yang kerja keras belum tentu bertawakal.

Relevansi nilai-nilai tarbiyah dalam ibadah kurban pada QS al-Ṣaffāt/37: 100-108 dengan pendidikan karakter tidak hanya menunjukkan sebuah relevansi, namun membuktikan keagungan al-Qur'an. Satu sejarah saja dalam al-Qur'an mengakomodasi seluruh nilai pendidikan yang hendak dikembangkan secara nasional di Indonesia. Sehingga demi mewujudkan revolusi mental yang digagas oleh pemerintah saat ini, tidak perlu menyibukkan diri guna mencari, memikirkan, dan merumuskan sistem pendidikan yang pas dan baik. Cukup berpatokan pada pendidikan Islam yang berlandaskan al-Qur'an dan alSunnah sebagai manifestasi dari agama Islam itu sendiri yang rahmatan li al-'álamin. 


\section{KESIMPULAN}

Berdasarkan pembahasan yang diuraikan sebelumnya, dapat ditarik kesimpulan sebagai berikut: Pertama, Sejarah ibadah kurban menurut QS al-Ṣaffāt/37: 100-108 dibagi menjadi empat episode, yaitu: (1) Harapan, Ibrahim menyampaikan harapannya kepada Allah SWT agar dikaruniakan seorang anak yang saleh, kemudian Allah SWT mengabulkan harapan tersebut dengan memberinya kabar gembira mengenai kelahiran anak yang sangat sabar (Ismail) sebagaimana disebutkan dalam QS al-Ṣaffāt/37: 100-101. (2) Ujian, Allah SWT menguji Ibrahim dengan memerintahkan menyembelih anaknya (Ismail) melalui mimpi dalam QS al-Ṣaffāt/37: 102. (3) Lulus ujian, Ibrahim berhasil lulus dari ujian Allah dengan upayanya untuk melaksanakan perintah penyembelihan sebagaimana disebutkan dalam QS alȘaffāt/37: 103-105. (4) Penghargaan, Allah memberi penghargaan kepada Ibrahim atas keberhasilannya melalui ujian yang sangat berat dengan mengabadikan pujian yang baik di kalangan orang-orang yang datang kemudian sebagaimana disebutkan dalam QS al-Ṣaffāt/37: 106-108.

Kedua, Sejarah ibadah kurban mengandung delapan nilai tarbiyah, yaitu: 1) Nilai pendidikan keimanan, 2) nilai pendidikan akhlak, 3) nilai pendidikan kesabaran, 4) nilai pendidikan tawakal, 5) nilai pendidikan keikhlasan, 6) nilai pendidikan demokratis, 7) nilai pendidikan dialogis, ditunjukkan ketika ibrahim dan ismail mendiskusikan mimpi penyembelihan, dan 8) nilai pendidikan sosial.

Ketiga, Sejarah tersebut dan berbagai nilai tarbiyah yang dikandungnya memiliki relevansi dengan karakteristik utama desain pembelajaran yang berimplikasi pada tahapan mendesain pembelajaran. Begitupun memiliki relevansi dengan proses pembelajaran yang terdiri atas perencanaan, pelaksanaan, evaluasi, dan tindak lanjut. Selain itu, mengakomodasi seluruh nilai yang hendak dikembangkan dalam pendidikan karakter.

Berdasarkan kesimpulan tersebut penelitian ini merekomendasikan perlunya reorientasi pembelajaran di Indonesia dari yang mengutamakan kognisi menuju yang mengutamakan afeksi. Hal ini sulit tercapai tanpa profesionalitas pendidik dalam menjalankan tugas, peran, dan tanggung jawabnya. Pendidik akan senantiasa berusaha untuk berbuat maksimal bila upayanya dalam mendidik didasari dengan rasa cinta terhadap keprofesiannya. Rasa cinta ini yang akan menumbuhkan keikhlasan, keikhlasan membuat pekerjaan terasa mudah dan mendatangkan berkah dari Allah SWT.

Pemerintah sebagai penentu kebijakan pendidikan hendaknya lebih memberi peran kepada pendidikan Islam. Sistem pendidikan Islam dapat dikonversi ke dalam sistem pendidikan nasional. Berdasarkan penelitian ini, satu sejarah saja dalam al-Qur'an sudah 
dapat mengakomodasi seluruh nilai-nilai karakter yang harus dikembangkan dalam setiap pembelajaran di Indonesia, apalagi bila dilakukan pengkajian yang lebih mendalam pada ayatayat berdimensi pendidikan lainnya dalam al-Qur'an, tentu akan ditemukan hal-hal baru mengenai pendidikan. Islam merupakan agama rahmatan li al-älamin, sehingga masyarakat yang plural di Indonesia sangat memungkinkan menerima sistem pendidikan Islam, apalagi yang dikonversi hanyalah sistem pendidikan Islam, bukan syariat secara utuh.

\section{DAFTAR PUSTAKA}

Abdullah, Assyari. "Komunikasi Simbolik Ibadah Kurban", RiauPos.co Edisi 25 September 2015, http://wnw.riaupos.co/4085-opini-komunikasi-simbolik-ibadah-kurban.html, Diakses 13 Januari 2018.

Ahmadi, Wahid. Risalah Akblak Panduan Perilaku Muslim Modern. Solo: Era Intermedia, 2004.

Amir, H. M. Kisab Nabi Ibrabim dalam Al-Qur'an dan Relevansinya dengan Pendidikan Islam. Ekspose, Vol. 23, No. 1 (2014): 1-22.

Amril. Akblak Tasawuf: Meretas Jalan Menuju Akblak Mulia. Bandung: Refika Aditama, 2015.

Amrullah, Abdul Malik Karim. Tafsir al-Az̧har, Juzz XXIII. Jakarta: Pustaka Panjimas, 2008.

Arikunto, Suharsimi. Dasar-dasar Evaluasi Pendidikan. Jakarta: Bumi Aksara, 2015.

Aryo, Muhammad Gatot. Keajaiban Ikblas: Cara Meraih Kesuksesan dan Kebahagiaan Hidup Dunia Akbirat. Jakarta: PT. Elexmedia Komputindo, 2007.

Assegaf, Abd. Rachman. Filsafat Pendidikan Islam: Paradigma Baru Pendidikan Hadhari Berbasis Integratif-Interkonektif. Jakarta: Rajawali Pers, 2011.

Barnadib, Sutari Imam. Pengantar Ilmu Pendidikan Sistematis. Yogyakarta: Andi Ofset 2007.

Burga, Muhammad Alqadri, Azhar Arsyad, Muljono Damopolii, dan A. Marjuni. Accommodating the National Education Policy in Pondok Pesantren DDI Mangkoso: Study Period of 1989-2018. Islam Realitas: Journal of Islamic \& Social Studies, Vol. 5, No. 1 (2019): 78-95.

Burga, Muhammad Alqadri. Hakikat Manusia sebagai Makbluk Pedagogik. Al-Musannif, Vol. 1, No. 1 (2019): 19-31.

Dangnga, Muhammad Siri, dan Andi Abd. Muis, Teori Belajar dan Pembelajaran Inovatif. Makassar: SIBUKU, 2015.

Departemen Agama RI, Al-Qur'an dan Tafsirnya: Edisi yang Disempurnakan, Jilid VIII. Jakarta: Departemen Agama RI, 2009.

Departemen Agama RI, Al-Qur'an dan Terjemahnya. Surabaya: Pustaka Assalam, 2010.

Hamdi, Asep Saepul, dan E. Baharuddin. Metodologi Penelitian Kuantitatif: Aplikasi dalam Pendidikan. Yogyakarta: Deepublish, 2014.

Al-Ḥanbalī, Ibnu 'Ādil. Al-Bäbu fì Ulūm al-Kitāb, Juz XVI. Bairut: Dar al-Kitab alIlmiyah, 1998. 
Hasan, Zainol. Nilai-nilai Pendidikan Islam pada Kisah Nabi Ibrahim. Nuansa: Jurnal Penelitian Ilmu Sosial dan Keagamaan Islam, Vol. 14, No. 2 (2018): 423-450.

Howe, Ruel. L. The Miracle of Dialogue. Terj. Muchtar Karyaman, Keajaiban Dialog. Jakarta: Nusa Indah, 2004.

Ibnu Kașīr. Tafsìr al-Qur'ān al-'Aẓim, Jilid VII. Kuala Lumpur Victory Agencie, 2006.

Ibnu Mājah, Sunan Ibn Mājah, Juz II. Bairut: Dar al-Fikr, 1997.

Ilyas, Yunahar. Kuliah Aqidah Islam. Yogyakarta: Lembaga Pengkajian dan Pengamalan Islam, 2002.

Jalaluddin. Teologi Pendidikan. Jakarta: Rajawali Press, 2001.

Kusuma, Iskandar Wiryo. Demokrasi Belajar dan Pembelajaran Ditinjau dari Pengalaman Empirik. Malang: IPTP, 2001.

Latifah, Nur. Pendidikan Islam di Era Globalisasi. PALAPA: Jurnal Studi Keislaman dan Ilmu Pendidikan, Vol. 5, No. 1 (2017): 196-208. https://doi.org/10.36088/palapa.v5i1.80.

Mahfud, Choirul. Tafsir Sosial Kontekstual Ibadah Kurban dalam Islam. Humanika, Vol. 14, No. 1 (2014): 1-16.

Al-Maḥallī, Jalāl al-Dīn, dan Jalāl al-Dīn al-Suyūtī. Tafsìr al-Qư'àn al-'Ażìm. Bandung: Sinar Baru Algesindo, 2011.

Al-Marāgī, Aḥmad Musțāfa. Tafïir al-Marāgì, Juzz XXIII. Semarang: Toha Putra, 1993.

Muhadjir, Noeng. Metode Penelitian Kualitatif. Yogyakarta: Rake Sarasih, 2002.

Nata, Abuddin. Kapita Selekta Pendidikan Islam. Jakarta: PT. Raja Grafindo Persada, 2012.

Noviati, Reni. Praktik Kurban Online dalam Perspektif Islam Tebar Hewan Kurban (THK) di Dompet Dhuafa. Syarikah: Jurnal Ekonomi Islam, Vol. 3, No. 1 (2017): 343-357.

Al-Qardawi, Yusuf. Al-Iman wa al-Hayat. Terj. Jazirotul Islamiyah, Merasakan Kebadiran Tuhan. Yogyakarta: Mitra Pustaka, 2007.

Al-Qurțubī. Tafsìr al-Qurțuī, Jilid XV. Jakarta: Pustaka Azzam, 2009.

Ramayulis. Filsafat Pendidikan Islam: Analisis Filosofis Sistem Pendidikan Islam. Jakarta: Kalam Mulia, 2015.

Rosyada, Dede. Paradigma Pendidikan Demokratis: Sebuab Model Pelibatan Masyarakat dalam Penyelenggaraan Pendidikan. Jakarta: Kencana, 2007.

Al-Ṣabūnī, Muḥammad 'Alī. Shafwah al-Tafasìr: Tafsìr li al-Qur'ān al-Karim, Jilid III. Jakarta Indonesia: Dar al-Kutub al-Islamiyyah: 1999.

Shihab, M. Quraish. Tafsir Al-Mishbab: Pesan, Kesan, dan Keserasian Al-Quran, Volume 12. Jakarta: Lentera Hati, 2009.

Sudijono, Anas. Pengantar Evaluasi Pendidikan. Jakarta: PT. Raja Grafindo Persada, 2008.

Sugiyono. Memahami Penelitian Kualitatif. Bandung: Alfabeta, 2008.

Supadie, Didiek Ahmad, et. al. Pengantar Studi Islam. Jakarta: Rajawali Pers, 2011. 
Suprayogo, Imam, dan Tabroni. Metode Penelitian Sosial-Agama. Bandung: Remaja Rosdakarya, 2001.

Suyanto, Bagong, et. al. Metode Penelitian Sosial: Berbagai Alternatif Pendekatan. Jakarta: Kencana, 2007.

Syukur, Amin. Tasawnf Bagi Orang Awam: Menjawab Problem Kehidupan. Yogyakarta: Pustaka Pelajar, 2006.

Ulwan, Abdullah Nasih. Tarbiyah al-Awläd. Terj. Minzar Hamid, Pendidikan Anak dalam Islam, Jilid II. Jakarta: Pustaka Amani, 2009.

Widadi, Achmad. Nilai Pendidikan pada Syariat Kurban: Kajian Tafsir Surat Al-Haij Ayat 34 dan Surat Al-Kautsar Ayat 1-3. Jakarta: FITK UIN Syarif Hidayatullah, 2016.

Yaumi, Muhammad. Prinsip-prinsip Desain Pembelajaran: Disesuaikan dengan Kurikulum 2013. Jakarta: Kencana, 2014.

Yunus, Firdaus M. Pendidikan Berbasis Realitas Sosial. Yogyakarta: Logung Pustaka, 2007. 